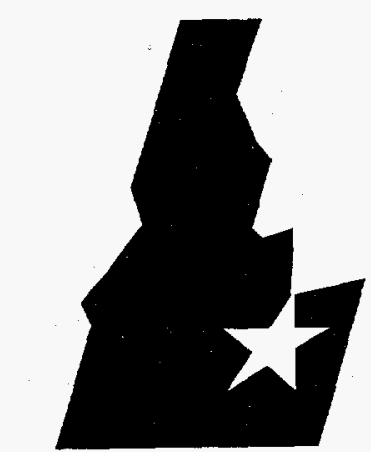

Idaho

National

Engineering

Laboratory
INEL-95/0460

September 1995
Commercial Disposal Options for Idaho National Engineering Laboratory LowLevel Radioactive Waste
Craig L. Porter

Derek A. Widmayer
OSTI

NOV 211950 


\title{
Commerical Disposal Options for Idaho National Engineering Laboratory Low-Level Radioactive Waste
}

\author{
Craig L. Porter \\ Jetseal, Inc.
}

Derek A. Widmayer

SAIC

Publisheố September 1995

\author{
Idaho National Engineering Laboratory \\ Waste Technology Planning and Projects Department \\ Lockheed Idaho Technologies Company \\ Idaho Falls, Idaho 83415
}

Prepared for the

U.S. Department of Energy

Under DOE Idaho Operations Office

Contract DE-AC07-941D13223

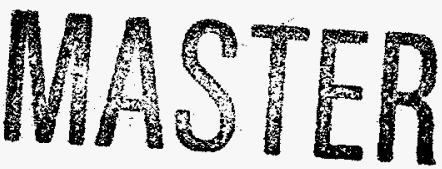




\begin{abstract}
The Idaho National Engineering Laboratory (INEL) is a Department of Energy (DOE)-owned, contractor-operated site. Significant quantities of low-level radioactive waste (LLW) have been generated and disposed of onsite at the Radioactive Waste Management Complex (RWMC). The INEL expects to continue generating LLW while performing its mission and as aging facilities are decommissioned. An on-going Performance Assessment process for the RWMC underscores the potential for reduced or limited LLW disposal capacity at the existing onsite facility. In order to properly manage the anticipated amount of LLW, the INEL is investigating various disposal options. These options include building a new facility, disposing the LLW at other DOE sites, using commercial disposal facilities, or seeking a combination of options. This evaluation reports on the feasibility of using commercial disposal facilities.
\end{abstract}

\title{
DISCLAIMER
}

\begin{abstract}
This report was prepared as an account of work sponsored by an agency of the United States Government. Neither the United States Government nor any agency thereof, nor any of their employees, makes any warranty, express or implied, or assumes any legal liability or responsibility for the accuracy, completeness, or usefulness of any information, apparatus, product, or process disclosed, or represents that its use would not infringe privately owned rights. Reference herein to any specific commercial product, process, or service by trade name, trademark, manufacturer, or otherwise does not necessarily constitute or imply its endorsement, recommendation, or favoring by the United States Government or any agency thereof. The views and opinions of authors expressed herein do not necessarily state or reflect those of the United States Government or any agency thereof.
\end{abstract}




\section{DISCLAIMER}

Portions of this document may be illegible electronic image products. Images are produced from the best available original document. 


\section{CONTENTS}

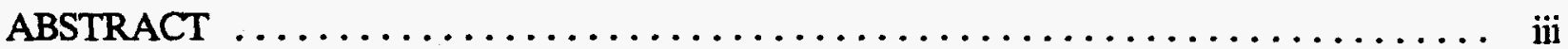

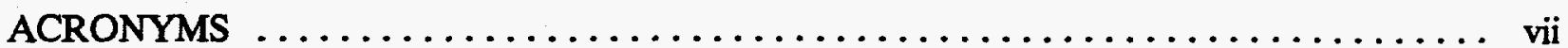

EXECUTIVE SUMMARY $\ldots \ldots \ldots \ldots \ldots \ldots \ldots \ldots \ldots \ldots \ldots \ldots \ldots \ldots \ldots \ldots \ldots$ ix

1. INTRODUCTION $\ldots \ldots \ldots \ldots \ldots \ldots \ldots \ldots \ldots \ldots \ldots \ldots \ldots \ldots \ldots \ldots \ldots$

2. REGULATORY EVALUATION $\ldots \ldots \ldots \ldots \ldots \ldots \ldots \ldots \ldots \ldots \ldots \ldots \ldots \ldots$

2.1 Statutory Framework For Commercial Disposal of INEL LLW . . . . . . . 2

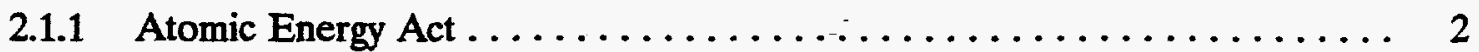

2.1.2 The Low-Level Radioactive Waste Policy Act $\ldots \ldots \ldots \ldots \ldots \ldots \ldots$

2.2 Compacts And States With Disposal Under The LLRWPAA . . . . . . . . 4

2.2.1 The Northwest Interstate Compact on Low-Level Radioactive Waste Management - Disposal Facilities at Richland, WA and Clive, UT ..... 5

2.2.2 Disposal Facility at Barnwell, SC $\ldots \ldots \ldots \ldots \ldots \ldots \ldots \ldots$

2.3 Regulatory Framework For Commercial Disposal Of INEL LLW $\ldots \ldots \ldots$

2.3.1 U.S. Nuclear Regulatory Commission - 10 CFR Part $61 \ldots \ldots \ldots \ldots$

2.3.2 U.S. Environmental Protection Agency - 40 CFR Part 193 . . . . . . . . . 9

2.4 DOE Policies On LLW Disposal $\ldots \ldots \ldots \ldots \ldots \ldots \ldots \ldots \ldots \ldots \ldots \ldots$

2.4.1 Historical DOE Headquarters Policies $\ldots \ldots \ldots \ldots \ldots \ldots \ldots \ldots \ldots \ldots$

2.4.2 DOE Order 5820.2A, Radioactive Waste Management $\ldots \ldots \ldots \ldots \ldots \ldots 12$

2.4.3 Recent DOE Headquarters Policies ..................... 12

2.4.4 DOE Order 5820.2B, Waste Management ................. 14

3. FACILITY EVALUATION $\ldots \ldots \ldots \ldots \ldots \ldots \ldots \ldots \ldots \ldots \ldots \ldots \ldots \ldots$

3.1 INEL LLW Baseline $\ldots \ldots \ldots \ldots \ldots \ldots \ldots \ldots \ldots \ldots \ldots \ldots \ldots \ldots \ldots \ldots \ldots$

3.2 Chem-Nuclear Systems Inc., Facility at Barnwell, South Carolina $\ldots \ldots \ldots \ldots \ldots$

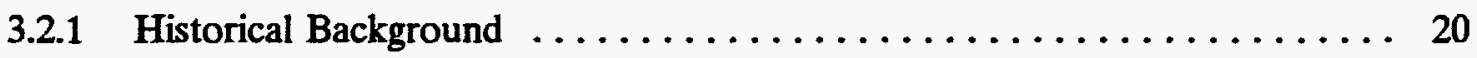

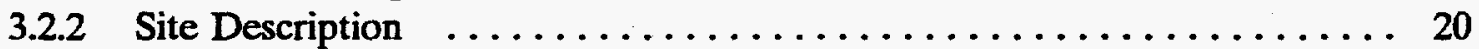

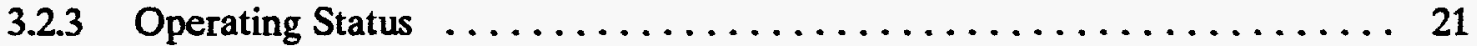

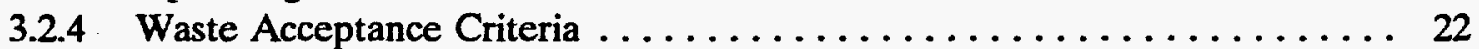

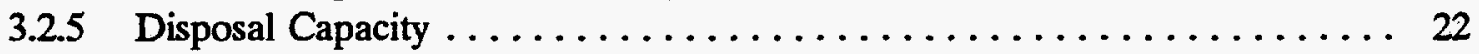

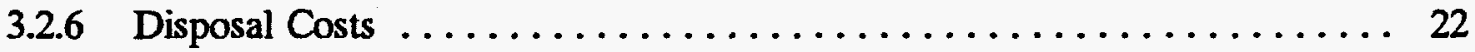


3.3 Envirocare of Utah Inc., Facility at Clive, Utah $\ldots \ldots \ldots \ldots \ldots \ldots$

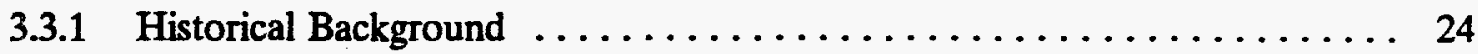

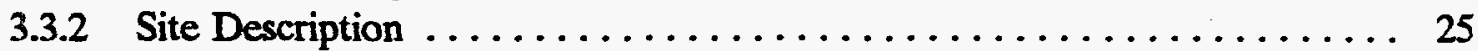

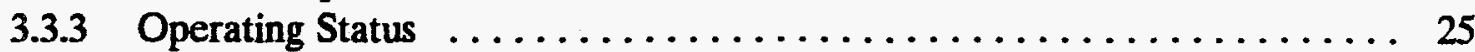

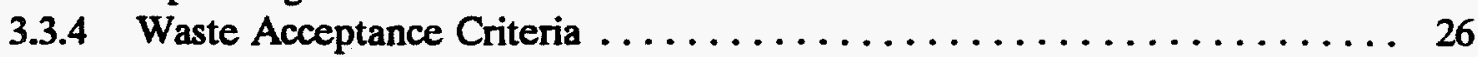

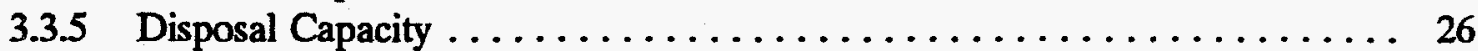

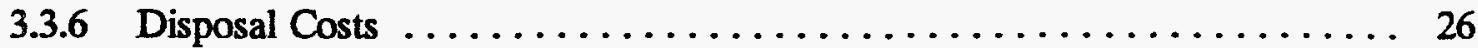

3.4 U.S. Ecology Facility at Richland, Washington $\ldots \ldots \ldots \ldots \ldots \ldots \ldots \ldots$

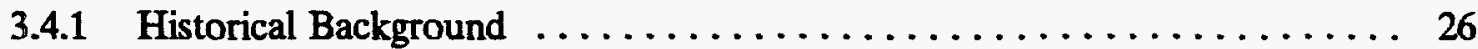

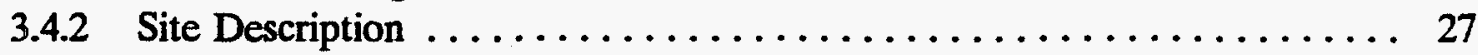

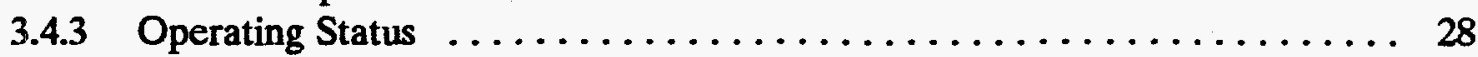

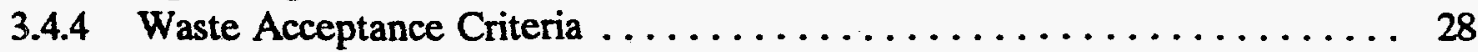

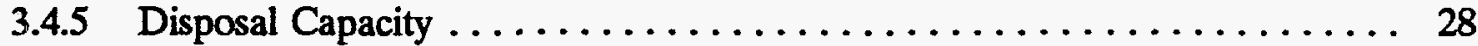

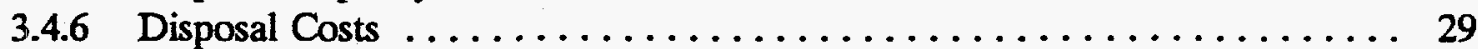

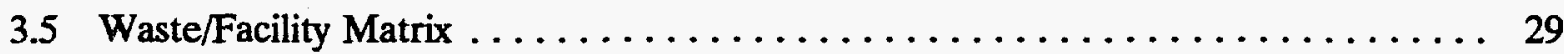

4. OTHER ISSUES $\ldots \ldots \ldots \ldots \ldots \ldots \ldots \ldots \ldots \ldots \ldots \ldots \ldots \ldots \ldots \ldots \ldots \ldots$

5. ANALYSIS AND CONCLUSIONS $\ldots \ldots \ldots \ldots \ldots \ldots \ldots \ldots \ldots \ldots \ldots \ldots \ldots$

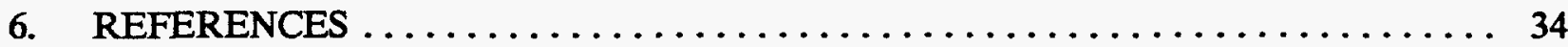

\section{FIGURES}

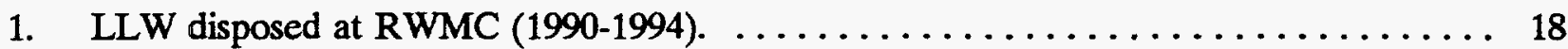

\section{TABLES}

1. Chronology of Department of Energy LLW disposal policy $\ldots \ldots \ldots \ldots \ldots \ldots \ldots \ldots 11$

2. Description of fields extracted from the $\mathrm{RWMIS} \ldots \ldots \ldots \ldots \ldots \ldots \ldots \ldots$

3. Selected information extracted from RWMIS $(90-94) \ldots \ldots \ldots \ldots \ldots \ldots \ldots$

4. NRC criteria vs. facility WACs $\ldots \ldots \ldots \ldots \ldots \ldots \ldots \ldots \ldots \ldots \ldots \ldots \ldots \ldots$

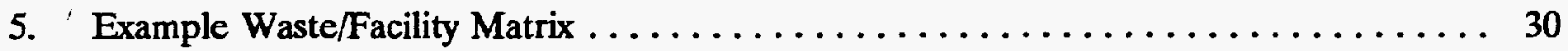




\section{ACRONYMS}

AEA

AEC

BTP

CFR

CNSI

DNFSB

DOE

EPA

FUSRAP

HIC

INEL

LLRWPAA

LLW

MLLW

NORM

NRC

RWMC

RWMIS

WAC

WERF
Atomic Energy Act

Atomic Energy Commission

branch technical position

Code Of Federal Regulations

Chem-Nuclear Systems, Inc.

Defense Nuclear Facilities Safety Board

U.S. Department Of Energy

U.S. Environmental Protection Agency

Formerly-Utilized Sites Remedial Action Program

high-integrity container

Idaho National Engineering Laboratory

Low-Level Radioactive Waste Policy Amendments Act

low-level radioactive waste

mixed low-level waste

naturally occurring radioactive material

U.S. Nuclear Regulatory Commission

Radioactive Waste Management Complex

Radioactive Waste Management Information System

waste acceptance criteria

Waste Experimental Reduction Facility 


\section{EXECUTIVE SUMMARY}

The Idaho National Engineering Laboratory (INEL) Radioactive Waste Management Complex (RWMC) was established in $\mathbf{1 9 5 2}$ as a disposal site for solid, low-level radioactive waste (LLW) and/or mixed low-level waste (MLLW), which contains hazardous and radioactive waste. These wastes were and are generated from operations at the INEL. An ongoing performance assessment process may possibly restrict future access to the RWMC for disposal of the INEL's LLW. One option being evaluated is using commercial LLW disposal facilities for the INEL's LLW. This report contains the results of that evaluation.

The feasibility study for commercial disposal focused on two primary areas, 1) a regulatory evaluation, and 2) an evaluation of waste acceptability at the three existing commercial LLW disposal facilities:

- Chem-Nuclear Systems facility at Barnwell, SC

- Envirocare of Utah facility at Clive, UT, and

- U.S. Ecology facility at Richland, WA.

Several laws, policies, regulations, and agreements govern the disposal of LLW. Specific laws include the Atomic Energy $\mathrm{Act}^{1}$ and the Low-Level Radioactive Waste Policy Act, ${ }^{2}$ along with amendments to these laws. ${ }^{3}$ Certain regulations of the U.S. Nuclear Regulatory Commission ${ }^{4}$ (NRC) and the U.S. Environmental Protection Agency (EPA)-proposed regulation 40 CFR 193 are also applicable to commercial LLW disposal. Another important regulatory area stems from commercial LLW compacts developed under the Low-Level Radioactive Waste Policy Amendments $\mathrm{Act}^{3}$ (LLRWPAA), and from individual states hosting commercial LLW disposal facilities. Finally, U.S. Department of Energy (DOE) policies and positions concerning commercial LLW disposal affect this disposal option. ${ }^{5}$

There are no statutory restrictions on the commercial disposal of DOE LLW. The LLRWPAA responsibility sections clarify congressional preferences on LLW generated by commercial interests and the Federal Government. However, the law does not prohibit the disposal of commercial LLW in DOE sites, nor DOE LLW in commercial sites. It could be argued that the framers of this law expected some of the crossover to take place. This is evidenced by the specified conditions that must be met for Federal Government LLW disposal in an area compact or state LLW disposal facility.

Furthermore, there are no restrictions placed on acceptance of DOE LLW by the Northwest Compact by-laws ${ }^{6}$ for either the Richland or Envirocare facilities. ${ }^{a}$ The by-laws state that the Compact can make any arrangements it desires with other states, compacts, or individual

a. Although not technically a "regional disposal facility" subject to the Northwest Compact, the Compact has passed resolutions regarding the operation of the Envirocare facility. The most recent (April 1995) authorizes access to the disposal facility for waste meeting Envirocare's license and approved by the compact of origin. 
generators. Since South Carolina withdrew from the Southeast Compact by repealing the compact legislation, there is no longer any legal authority for South Carolina to restrict access to the Barnwell facility. The regulatory framework for commercial LLW disposal contains no special restrictions or provisions that would affect disposal of INEL LLW.

However, there are two areas where potential barriers could arise. One is within the DOE itself. Current DOE policy is to manage waste onsite, at other DOE sites, or finally by the commercial sector. The policy is in a state of flux with the on-going effort to revise DOE Order 5820.2A, Radioactive Waste Management. ${ }^{7}$ The DOE's most recent statements regarding LLW disposal assure the compacts that it will not interfere with the disposal process being implemented under the LLRWPAA. The second potential for barriers is acceptance of the idea by regulators, compact commissions, and the general public. South Carolina may be receptive to receiving LLW for disposal with the recent changes within the SE Compact. However, regulators could not be contacted for this feasibility study and this area was not explored.

Using the last five years of LLW disposal at the RWMC as a baseline, and comparing that baseline to the waste acceptance criteria (WAC) of the respective commercial disposal facilities, a significant portion of the INEL LLW could be acceptable (70-80 percent at Barnwell and Richland, 20-25 percent at Envirocare). Sufficient excess capacity exists at these disposal facilities. Accepting expected quantities of INEL LLW at these facilities would not result in capacity shortages for other generators.

Disposal of qualified LLW at Envirocare could be pursued immediately for the following reasons: 1) Envirocare has the established niche (high-volume, very low-activity waste), 2) an identified inventory of INEL LLW will likely meet Envirocare's acceptance criteria, 3) the precedent already exists for disposal of DOE waste at Envirocare, and 4) a cost-effective contract is in place for use by Federal entities. Disposal at either of the other commercial facilities, while technically feasible for 70-80 percent of the projected INEL LLW, is affected by political and policy issues. Resolution of these issues is contingent on noncommercial option decisions. 


\section{INTRODUCTION}

The INEL Radioactive Waste Management Complex was established in 1952 as a disposal site for solid, low-level radioactive waste and/or mixed low-level waste generated by operations at the Idaho National Engineering Laboratory. The Department of Energy Order 5820.2A, Radioactive Waste Management, ${ }^{7}$ requires that a performance assessment be performed for waste disposal facilities such as the RWMC. The performance assessment evaluates compliance with the performance objectives established to protect the public, worker health, and the environment. Per DOE guidance, the performance assessment considered waste which had been disposed since 1988. Subsequent guidance requires that all INEL buried waste be included in the performance assessment, which could greatly restrict future access to the RWMC for disposal of the INEL's LLW.

The Waste Technology Planning and Projects Department of the Lockheed Idaho Technologies Company Waste Operations Branch initiated a fast-track LLW disposal study. The study is being conducted in order to better assess cost-effective alternatives for future disposal of INEL-generated LLW. The study includes RWMC expansion, building a new disposal facility, using other existing DOE disposal facilities, and using existing commercial disposal facilities. A preliminary comparison was conducted of INEL LLW against the waste acceptance criteria (WAC) of the candidate commercial facilities. A formal feasibility study of the commercial options was commissioned to validate the preliminary evaluation. This report documents the findings of that formal feasibility study.

The feasibility study focused on two primary areas, 1) a regulatory evaluation, and 2) an evaluation of waste acceptability. For the regulatory evaluation, applicable laws, regulations, policies, and agreements were identified and reviewed. The review identified requirements and issues bearing on the commercial disposal options. Current information (WACs, licenses, etc.) was obtained from each of the existing commercial LLW disposal facilities:

- Chem-Nuclear Systems facility at Barnwell, SC

- Envirocare of Utah facility at Clive, UT, and

- U.S. Ecology facility at Richland, WA.

The LLW waste disposal history from the RWMC was compiled for the period from 1990 through 1994 to establish a waste baseline for comparison with the respective WACs. This period was selected due to data availability, data completeness, and the likelihood of it being more representative of future disposal trends than less recent data. The results of the two evaluations were used to draw conclusions regarding the feasibility of the commercial disposal options. 


\section{REGULATORY EVALUATION}

Several laws, policies, regulations, agreements, and other documents govern the disposal of LLW. This section provides an overview and evaluation of the regulatory framework for commercial disposal of INEL LLW. Specifically, the Atomic Energy Act ${ }^{1}$ and the Low-Level Radioactive Waste Policy $\mathrm{Act}^{2}$ are discussed, along with amendments to these laws important to commercial disposal of INEL LLW. The regulations of the U.S. Nuclear Regulatory Commission ${ }^{4}$ and the U.S. Environmental Protection Agency applicable to commercial LLW disposal are covered. The current situation concerning commercial LLW compacts developed under the LowLevel Radioactive Waste Policy Amendments Act, ${ }^{3}$ and with individual states hosting commercial LLW disposal facilities is discussed. Finally, Department of Energy policies and positions concerning commercial LLW disposal are discussed.

\subsection{Statutory Framework For Commercial Disposal Of INEL LLW}

Two laws provide the statutory framework which would govern the commercial disposal of INEL LLW. These laws are the Atomic Energy Act of 1954, as amended, and the Low-Level Radioactive Waste Policy Act of 1980, as amended.

\subsubsection{Atomic Energy Act}

The Atomic Energy Act (AEA) of 1954, (Public Law 83-703), ${ }^{1}$ as amended, provides DOE the authority to manage the radioactive materials used in the operation of its facilities. It also provides for managing inactive sites that contain radioactive contamination from weapons production and other specified activities. This authority governs the disposal of the DOE's LLW, including the regulation of the disposal.

The AEA (amended by the Energy Reorganization Act of 1974) assigned the responsibility for regulation of non-DOE management of radioactive materials, including disposal, to the U.S. Nuclear Regulatory Commission (NRC). The NRC regulates commercial and non-DOE Federal Government disposal of low-level radioactive waste, but does not manage the facilities. ${ }^{5}$

Under the AEA, as amended, the NRC can enter into an agreement with a state to delegate the authority for regulation of radioactive materials to the state, if it is qualified. These Agreement States then may assume the regulatory responsibility for commercial disposal of LLW within their borders, provided it is part of the agreement with the NRC. In 1981, the NRC determined that qualified states could enter into limited agreements solely for the regulation of commercial LLW within their borders, and not for any other uses of radioactive material. Even under the agreements, NRC still retains regulatory authority over certain items, activities, and critical amounts and types of radioactive materials. At the present time, there are 26 Agreement States with the authority to regulate commercial disposal of LLW. The commercial disposal facilities currently operating are all located in current NRC Agreement States. 


\subsubsection{The Low-Level Radioactive Waste Policy Act}

The Low-Level Radioactive Waste Policy Act of 1980, (Public Law 96-573), ${ }^{2}$ assigned the States the responsibility for the disposal of LIW generated within their borders. Exceptions included certain LLW owned or generated by the Federal Government, or which otherwise was the responsibility of the Federal Government. The Act encouraged the formation of interstate "compact regions." From January 1, 1986, it offered authority to Congressionally-approved interstate compacts to restrict access to their disposal facilities to LLW generated within the region.

By the mid-1980s, it became obvious that disposal capability would not be established within regional compacts which did not host one of the operating commercial LLW disposal facilities. Thus, the Low-Level Radioactive Waste Policy Amendments Act of 1985 (Public Law 99-240) ${ }^{3}$ was passed. It extended the time that the operating facilities would be accessible to out-ofcompact LLW. In exchange for this extension, the LLRWPAA included a system of milestones. It included disincentives for missing milestones to encourage states and compacts without operating commercial LLW disposal sites to establish disposal capability.

The LLRWPAA specified the LLW for which the Federal Government would have disposal responsibility. Section 3 of the LLRWPAA states:

\section{SEC. 3. RESPONSIBILITIES FOR DISPOSAL OF LOW-LEVEL RADIOACTIVE WASTE.}

(b)(1) The Federal Government shall be responsible for the disposal of -

(A) low-level waste owned or generated by the Department of Energy;

(B) low-level waste owned or generated by the United States Navy as a result of the decommissioning of vessels of the United States Navy;

(C) low-level waste owned or generated by the Federal Government as a result of any research development, testing, or production of any atomic weapon; and

(D) any other low-level radioactive waste with concentrations of radionuclides that exceed the limits established by the Commission for class $C$ radioactive waste, as defined by section 61.55 of title 10, Code of Federal Regulations, as in effect on January 26, 1983.

Since it was not explicitly stated, it was assumed, and is now agreed that the Department of Energy is responsible for the disposal of the LLW specified above which the statute makes the responsibility of "the Federal Government."

Other provisions of the LLRWPAA have direct applicability to the commercial disposal of INEL LLW. Section 4 of the Act contains the following provisions: 
SEC. 4. REGIONAL COMPACTS FOR DISPOSAL OF LOW-LEVEL RADIOACTIVE WASTE.

(b) Applicability to Federal Activities.-

(1) IN GENERAL.-

(A) ACTIVITIES OF THE SECRETARY.- Except as provided in subparagraph $(B)$, no compact or action taken under a compact shall be applicable to the transportation, management, or disposal of any low-level radioactive waste designated [as Federal Government responsibility] in section $3(a)(1)(B)$ (i)-(iii).

(B) FEDERAL LOW-LEVEL RADIOACTIVE WASTE DISPOSED OF AT NON-FEDERAL FACILITIES.- Low-level radioactive waste owned or generated by the Federal Government that is disposed of at a regional disposal facility or non-Federal disposal facility within a State that is not a member of a compact shall be subject to the same conditions, regulations, requirements, fees, taxes, and surcharges imposed by the compact commission and by the State in which such facility is located, in the same manner and to the same extent as any low-level radioactive waste not generated by the Federal Government.

(2) FEDERAL LOW-LEVEL RADIOACTIVE WASTE DISPOSAL FACILITIES.- Any low-level radioactive waste disposal facility established or operated exclusively for the disposal of low-level radioactive waste owned or generated by the Federal Government shall not be subject to any compact or any action taken under a compact.

Therefore, if LLW generated by the DOE is disposed at a commercial LLW disposal facility, it would have the same regulations, fees, taxes, surcharges, and conditions placed on it that would be placed on commercial LLW to be disposed at the facility.

Another important provision in the LLRWPAA plays a role in the possible commercial disposal of INEL LLW. Section 7 of the Act assigns the Department the responsibility of providing financial and technical assistance to states and compacts for establishing new LLW disposal capacity.

\subsection{Compacts And States With Disposal Under The LLRWPAA}

When the LLRWPAA was signed into law, there were three operating commercial LLW disposal facilities in the U.S. They were located at Barnwell, SC; Beatty, NV; and at Richland, WA. The LLRWPAA contained provisions limiting the annual volumes that could be received at these facilities until January 1, 1993, at which time access to the facilities could be restricted for out-of-region LLW, or the facilities could be closed. Congress delineated the 
January 1, 1993, date with expectation that by that date, additional disposal capacity at new regional facilities would be available.

Shortly after the passage of the LLRWPAA, the states where the three operating commercial disposal facilities were located became the states for the three compact regions consented to by Congress. The Barnwell facility became the regional facility in the Southeast Interstate Low-Level Radioactive Waste Management Compact Region, the Richland facility became the regional disposal facility in the Northwest Interstate Compact on Low-Level Radioactive Waste Management, and the Beatty facility became the regional disposal facility in the Rocky Mountain Low-Level Radioactive Waste Compact Region.

At this date, there are still three operating commercial LLW disposal facilities in the U.S. The Beatty, NV facility was closed on December 31, 1992, as allowed under the LLRWPAA. The Clive, UT disposal facility was opened in February 1988. It was developed outside of the compact framework to accommodate large volumes of waste containing very low levels of radioactivity.

The current situation is somewhat complicated with the operating commercial LLW disposal facilities, their relationships with congressionally-consented compacts, and the affect this situation has on possible acceptance of INEL LLW at a commercial disposal facility. The following sections explore the background and situation with the operating LLW disposal facilities. The background with compacts and states that are attempting to establish new commercial LLW disposal capacity under the LLRWPAA, but have not yet succeeded, is not discussed in this study.

\subsubsection{The Northwest Interstate Compact on Low-Level Radioactive Waste Management - Disposal Facilities at Richland, WA and Clive, UT}

The Northwest Interstate Compact on Low-Level Radioactive Waste Management (Northwest Compact) includes the member states of Washington, Alaska, Hawaii, Idaho, Montana, Oregon, Utah, and Wyoming. The host state is Washington, with its currently operating regional disposal facility located at Richland, WA.

The Washington State Department of Health is responsible for regulating the regional disposal facility, while the Washington Department of Ecology is responsible for managing the facility's contractual arrangements with the State. The facility is operated by U.S. Ecology, Inc.

The Northwest Compact was given Congressional consent in December 1985 and signed by the President in January 1986. The Northwest Compact Committee and the Rocky Mountain Low-Level Radioactive Waste Compact Region Board signed an agreement in October 1992. This agreement allows the member States (Nevada, Colorado, and New Mexico) of the Rocky Mountain Compact to use the facility at Richland, WA for the disposal of LLW generated in that compact. Thus, the member States of the Rocky Mountain Compact had access to an open LLW disposal facility to replace the Beatty, NV LLW disposal facility, which was operating as the regional facility for the Rocky Mountain Compact until it closed on January 1, 1993.

The by-laws of the Northwest Compact Committee ${ }^{6}$ contain provisions for committee membership and composition. The by-laws include duties of the committee and the chairman of 
the committee, conduct of meetings, voting, financial support, and conduct of committee staff. The provisions of the compact by-laws that are important to possible acceptance of INEL LLW at a Northwest Compact regional disposal facility are:

\section{PURPOSE AND FUNCTION}

The Northwest Interstate Compact on Low-Level Radioactive Waste Management establishes a Compact Committee . . The Compact Committee is empowered to enter into arrangements relating to low-level radioactive waste with other states, provinces, individual generators, or other regional compact entities...

\section{ACCEPTANCE OF OUT-OF-REGION WASTE}

The Compact Committee may enter into arrangements with states, provinces, individual generators, or regional compact entities for access to the facility in accordance with such terms and conditions as the Committee may deem appropriate. .

The Envirocare facility in Clive, UT was first opened in February 1988 for the disposal of low-activity naturally-occurring radioactively-contaminated wastes. This specific kind of radioactive waste is not included in the definition of low-level waste in the LLRWPAA. Therefore, when the facility opened, it was technically not a LLW disposal facility under the LLRWPAA. Shortly thereafter, the license from the State of Utah for the Envirocare facility was amended to allow for disposal of low-activity low-level radioactive wastes containing radionuclides other than naturally-occurring. However, the intent of the operators was to provide a disposal facility for high-volume low-activity LLW consisting of soils and rubble generated as a result of cleanups and decommissioning projects. The Northwest Compact Commission issued a Resolution and Order providing the permission of the Compact for Envirocare to continue operating within the Compact(see Reference 9).

The initial Resolution and Order was issued in December 1991, and amended by a few clarifying amendments issued since then. The Resolution and Order contains provisions spelling out the terms and conditions under which Envirocare may continue to accept LLW. The provisions of the December 1991 Resolution and Order, as amended, made it clear that the facility was to accept cleanup waste associated with a closure or decommissioning of facilities. No LLW from routine operations or routine cleanups are allowed.

However, a revision of the Resolution and Order was issued in April 1995 removing the restriction that LLW acceptable at the facility must be associated with closure and decommissioning. ${ }^{10}$ The conditions for acceptance of LLW still specify large-volume soil, soil-like materials, and debris, but the revised resolution allows waste which is generated from operations and routine cleanups. Envirocare's license still restricts such waste to that containing very low levels of radioactivity.

Another relevant fact about the Envirocare facility could impact the possible disposal of INEL LLW at a commercial disposal facility. In 1991, the Envirocare facility obtained a permit 
from the State of Utah to dispose of mixed LLW. Therefore, mixed LLW, if it meets the conditions of the facility's license, is acceptable for disposal at Envirocare. The April 1995 Resolution and Order specifies that all mixed LLW streams are acceptable, not just large-volume soil and soil-like $L L W$, and debris.

\subsubsection{Disposal Facility at Barnwell, SC}

The commercial LLW disposal facility at Barnwell, SC became the regional disposal facility for the Southeast Interstate Low-Level Radioactive Waste Management Compact Region upon approval of the compact in January 1986. The operator of the Barnwell, SC LLW disposal facility is Chem-Nuclear Systems, Inc. The facility is regulated by the South Carolina Department of Health and Environmental Control.

The Barnwell, SC disposal facility has gone through various phases of availability to other compacts and non-Southeast compact states since formation of the Southeast Compact. The original compact legislation called for South Carolina, containing the Barnwell facility, to be the host state for the region until January 1, 1993, and to allow access to the facility to other nonmember states that met appropriate conditions tied to achievements called out in the LLRWPAA.

The South Carolina legislature passed legislation in late 1992 to allow non-member states to have continued access to the Barnwell facility through June 30, 1994. This continued access was restricted if states did not meet certain conditions (see Reference 9).

From July 1, 1994, until July 1, 1995, the facility was still the regional facility for the Southeast Compact, but access to the facility was limited to member states of the compact. This limitation, combined with the restrictions in place in the Northwest Compact, meant that the majority of states in the country were without access to an operating LLW disposal site. However, in the brief time that Barnwell's access was limited, South Carolina's legislature realized that accepting and surcharging LLW from non-Southeast Compact states could offer budget relief. Thus, early in 1995 the Governor of South Carolina began exploring the options for re-opening access to Barnwell.

In Spring of 1995, the Southeast Compact Commission declined to approve a proposal from the Governor of South Carolina. He proposed to open access to the Barnwell, SC disposal facility to others, except for members states of the Northwest and Rocky Mountain Compacts

(who had access to LLW disposal), and North Carolina. ${ }^{11}$ The proposal was unsuccessful probably because the Governor wanted to restrict access for North Carolina generators to force North Carolina to make faster progress on development of the Southeast Compact facility intended to replace Barnwell. ${ }^{12}$

Therefore, on June 13,1995, the South Carolina legislature included provisions in the fiscal year budget legislation effectively seceding from the Southeast Compact and re-opening access to the Barnwell facility to all states except North Carolina. These provisions took effect at the start of the state's fiscal year, July 1, 1995. Since South Carolina is no longer a member of any regional compact, they cannot legally restrict access to the Barnwell facility to any state at this time. 
As of this date, the operator of the Barnwell, SC facility, Chem-Nuclear Systems, Inc., is negotiating disposal contracts with generators outside of the Southeast region to accompany their existing contracts with Southeast Compact member states (see Reference 12). LLW accepted at Barnwell is surcharged at the rate of $\$ 235$ per cubic foot, with most of the tax revenues allocated for the South Carolina Educational Assistance Endowment Fund.

\subsection{Regulatory Framework For Commercial Disposal Of INEL LLW}

Two Federal agencies provide the framework defining the regulations that govern the commercial disposal of INEL LLW. These agencies are the U.S. Nuclear Regulatory Commission (NRC) and the U.S. Environmental Protection Agency (EPA). The NRC was given the authority to regulate commercial and certain Federal uses of radioactive materials, including commercial disposal of LLW, by the Energy Reorganization Act of 1974. The EPA was given the authority to establish generally-applicable environmental standards for the protection of the environment from radiation and radioactive materials by Reorganization Plan No. 3, which created the EPA.

\subsubsection{U.S. Nuclear Regulatory Commission - 10 CFR Part $61^{4}$}

The NRC licensing requirements for commercial low-level waste disposal facilities are found in 10 CFR Part 61, Licensing Requirements for Land Disposal of Radioactive Waste. Part 61 was issued in December 1982 following a period of approximately five years for rulemaking under the Administrative Procedures Act.

Part 61 contains provisions to regulate the entire life-cycle of LLW which is considered to be a hazard. Regulation is from LLW generation through disposal and for a period of time following closure of the disposal facility (approximately $\mathbf{5 0 0}$ years). There are technical, financial, and procedural requirements in Part 61 to assure protection of the public health and safety and the environment throughout this entire hazardous life of the waste.

The cornerstone of the regulations in Part 61 are the performance objectives found in Subpart C. These four performance objectives address protection of (1) the public from releases of radioactivity from the facility, (2) the inadvertent intruder, (3) the workers at the facility, and (4) the stability of the site following emplacement of the waste. Throughout the lifetirne of the facility, there must be reasonable assurance that these objectives will be met.

The regulation also contains technical requirements in Subpart D in the form of technical objectives as well as prescriptive requirements for waste form and waste classification, disposal site suitability, disposal facility design, facility operations and closure, institutional care, and environmental monitoring. Subpart $E$ of the regulation contains requirements for financial assurances so the disposal site operator will assume the costs of operating, closing, and stabilizing the site and will provide finances for the period of institutional control required by the regulations.

The regulation also contains administrative requirements concerning employee protection,

involvement of states and Indian Tribes, recordkeeping, tests, and other subjects in Subparts A, F, and $G$ of Part 61. Subpart B of Part 61 contains the requirements defining what information 
must be included in a license application to the NRC. It includes requirements for siting, designing, and operating a commercial LLW disposal facility. Information is also included on the process that the applicant must follow for submittal and review of the application.

Under Section 274 of the Atomic Energy Act, NRC can relinquish portions of its regulatory authority to a state. States may assume authority in place of the NRC for licensing facilities that use radioactive material if an agreement between the governor of the state and the NRC is negotiated. In assuming the authority over licensing, the state agrees to maintain continuing "compatibility" with the NRC's regulatory program. Under an agreement with NRC, states can assume the licensing authority over LLW disposal facilities.

For many years, the licensing of commercial LLW disposal facilities has been done primarily by Agreement States. Presently, all three facilities for the disposal of commercial LLW operate under a radioactive materials license issued by the state under its agreement with the NRC.

If INEL LLW were to be disposed at any of the three operating commercial LLW disposal facilities, the regulations in effect in these Agreement States would have to be met in order for the LLW to be acceptable for disposal at the sites.

\subsubsection{U.S. Environmental Protection Agency - 40 CFR Part $193^{13}$}

The EPA has been working on the establishment of a generally applicable environmental standard for the management and disposal of LLW since the early 1980s. The latest version of the standard was distributed as a "preproposal draft" to specific interested parties for comments in December 1994. Comments received by the EPA on the preproposal draft led them to announce on July 13,1995, that they were discontinuing the development of the generally-applicable standards for disposal facilities licensed by NRC and Agreement States. They believe that the protection standards included in 10 CFR Part 61 are sufficient and that issuance of another set of requirements at this time would disrupt the process of developing new disposal capacity.

However, the EPA will be proceeding with establishment of generally applicable environmental standards for management and disposal of DOE LLW. The EPA was originally aiming for a fall 1995 issuance date for the proposed standard. It has delayed this to February 1996 in order for the agency to consider some differences in the disposal practices of the DOE that were not included in the preproposal draft. ${ }^{14}$

The promulgation of an EPA standard specifically for DOE LLW disposal facilities, if it is consistent with the preproposal draft, could have a propitious impact on the potential for commercial disposal of INEL LLW. The preproposal draft issued in late 1994 proposed Federal groundwater protection standards which varies with those applied at commercial disposal facilities. If the EPA were to go forward with the groundwater protection standards in the DOE LLW rulemaking, it could mean that INEL LLW would need to meet a less stringent environmental standard for disposal at a commercial LLW disposal facility compared to a DOE LLW disposal facility. 


\subsection{DOE. Policies On LLW Disposal}

The DOE policies on disposal of LLW are primarily reflected in DOE Order 5820.2A, Radioactive Waste Management, issued in September 1988. ${ }^{7}$ The policies in the Order that bear the most importance concerning the disposal of INEL LLW in a commercial facility were developed over a period of several years preceding the issuance of the Order (see Table 1). Since issuance of Order 5820.2A, circumstances have occasionally arisen that have called for clarifications and interpretations of policies and requirements in the Order for certain LLW disposal situations. These refinements serve to establish additional policies concerning LLW disposal, especially the disposal of DOE LLW in commercial facilities. The DOE is in the process of revising the radioactive waste management order again, to DOE Order 5820.2B.

\subsubsection{Historical DOE Headquarters Policies}

In May 1963, the Atomic Energy Commission (AEC) issued a memorandum urging its waste generators to use the newly-established commercial LLW disposal facilities. This marked a period of over 15 years during which AEC and later DOE generators used both Department and commercial LLW disposal facilities. Large Department sites, sites which were engaged in major weapons production activities, had their own disposal facilities. The smaller laboratories and research and development projects used the commercial facilities.

The DOE responded to situations in commercial LLW disposal (temporary shutdown of the Nevada and Washington facilities), that were threatening the continued availability of the operating LLW disposal sites to all generators of LLW. The DOE ordered the Field Elements to stop using commercial LLW disposal, and to establish disposal capacity with one of the currentlyoperating DOE facilities. An urgent telecommunication to this end was carried out and documented in October 1979.15 A November 1979 memorandum from the Office of Nuclear Waste Management in the Office of Defense Programs clarifies anu expands on the October 1979 directive. ${ }^{16}$ The position of the Department concerning the commercial LLW disposal situation is indicated by this statement in the November 1979 memorandum:

\section{All personnel should realize the importance that DOE places on being able to} alleviate its impact on the commercial burial sites.

Shortly after the Department voluntarily directed its LLW away from the commercial disposal sites, the Low-Level Radioactive Waste Policy Act further added to this directive by taking the first step in assigning responsibility for Federally-generated LLW to the government.

A May 11, 1987, memorandum from the Assistant Secretary for Defense Programs to the Field Managers superseded the guidance in the two 1979 memoranda (and two subsequent memoranda on similar subjects). ${ }^{17}$ The policies most important to commercial disposal of INEL LLW in the May 1987 policy are stated:

1. DOE $L L W$ should be managed onsite unless such action is incompatible with long-range site plans. 
Table 1. Chronology of Department of Energy LLW disposal policy.

\begin{tabular}{|c|c|}
\hline Year & Policy actions, documents, explanations \\
\hline \multicolumn{2}{|c|}{1946 - 1960 : AEC DISPOSAL AT AEC SITES } \\
\hline 1954 & $\begin{array}{l}\text { - ATOMIC ENERGY ACT - amended, AEC licensing of commercial uses of } \\
\text { radioactive materials begins. }\end{array}$ \\
\hline 1957 & $\begin{array}{l}\text { - Commercial generation of radioactive waste begins - disposal onsite by some } \\
\text { licensees. }\end{array}$ \\
\hline \multicolumn{2}{|c|}{1960 - 1963 : AEC AND COMMERCIAL DISPOSAL AT AEC SITES } \\
\hline 1960 & $\begin{array}{l}\text { - AEC announces INEL and ORNL disposal facilities to be used for commercial } \\
\text { LLW disposal until commercial facilities are opened. }\end{array}$ \\
\hline \multicolumn{2}{|c|}{1963 - 1979 : AEC (DOE) DISPOSAL AT BOTH AEC (DOE) AND COMMERCLAL SITES } \\
\hline 1963 & $\begin{array}{l}\text { - AEC memo directs sites without disposal facilities to use commercial sites for } \\
\text { disposal of unclassified LLW. }\end{array}$ \\
\hline \multicolumn{2}{|c|}{$\begin{array}{l}1979 \text { - } 1991 \text { : DOE DISPOSAL AT DOE SITES; COMMERCIAL DISPOSAL AT } \\
\text { COMMERCIAL SITES }\end{array}$} \\
\hline \multicolumn{2}{|c|}{$\begin{aligned} 1979 & \text { Oct } 79- \\
\text { Nov } 79- & \text { DOE Telecom directing sites using commercial LLW disposal facilities to } \\
\text { stop. } & \text { DOE Memo provides guidance implementing Oct directive; assigns DOE } \\
& \text { generators to DOE disposal facilities. }\end{aligned}$} \\
\hline \multicolumn{2}{|r|}{$\begin{array}{l}\text { Jun } 80 \text { - DOE memo clarifying DOE policies concerning DOE and commercial LLW } \\
\text { disposal } \\
\text { Dec } 80 \text { - LOW-LEVEL RADIOACTIVE WASTE POLICY ACT - establishes states } \\
\text { responsible for commercial LLW ; encourages Compacts. }\end{array}$} \\
\hline 1984 & $\begin{array}{l}\text { - DOE Order } 5820.2 \text {, Radioactive Waste Management issued. Chapter III on LLW } \\
\text { includes policy that DOE waste should be disposed at DOE sites. }\end{array}$ \\
\hline 1986 & - LOW-LEVEL RADIOACTIVE WASTE POLICY AMENDMENTS ACT \\
\hline 1987 & $\begin{array}{l}\text { - DOE Memo issued- Policy continues that DOE LLW should be managed onsite; } \\
\text { detailed guidance provided. }\end{array}$ \\
\hline 1988 & $\begin{array}{l}\text { Mar } 88 \text { - DOE Memo - commercial facility use not expressly forbidden, but not in } \\
\text { DOE's best interest. } \\
\text { Sep } 88 \text { - - DOE Order } 5820.2 \mathrm{~A} \text { issued. Chapter III on LLW includes policy that DOE } \\
\text { waste should be managed within the DOE Complex. }\end{array}$ \\
\hline \multicolumn{2}{|c|}{1991 - present : DOE DISPOSAL AT BOTH DOE AND COMMERCIAL SITES } \\
\hline 1991 & - Case-by-case exemptions to 5820.2A start for commercial disposal of DOE LLW. \\
\hline 1993 & $\begin{array}{l}\text { Nov } 93 \text { - EM-1 approves generic } 5820.2 \mathrm{~A} \text { exemption for commercial disposal of } \\
\text { certain LLW. }\end{array}$ \\
\hline 1994 & $\begin{array}{l}\text { Jan } 95 \text { - DOE assurance to LLW Forum of its commitment to maintain disposal } \\
\text { responsibility for its waste }\end{array}$ \\
\hline
\end{tabular}


2. DOE LLW should generally be disposed of at DOE disposal facilities. Existing arrangements between generator and disposal sites should be maintained.

3. DOE LLW generated on a site that does not have a $L L W$ disposal facility should be disposed of at a DOE site that has such a facility. The waste volume and number of shipments should be minimized.

A clear position on DOE use of commercial disposal facilities was issued from the Office of Defense Programs in a March 3,1988, memorandum to the Office of Remedial Action and Waste Technology. ${ }^{18}$ In that memorandum, the Acting Deputy Assistant Secretary for Defense Programs responded to questions prompted by an inquiry from U.S. Ecology, Inc., a company interested in obtaining business from the Department for disposal of LLW from Formerly Utilized Sites Remedial Action Program (FUSRAP) projects. To quote from this memorandum:

While DOE Order 5820.2 and the supplemental guidance provided by the ASDP memorandum of May 11, 1987, do not explicitly prohibit use of commercial disposal facilities at present, it is our opinion that such use of commercial facilities is not in the Department's best interests at this time.

An important aspect of the Department's policies as they were being established during this period was the role the Department was assigned by Congress to assist the compacts and states with new disposal capacity development. Since the Department could manage its own LLW, it was believed that use of commercial disposal facilities was unnecessary. Compacts and states did not include DOE LLW in the planning base for new disposal capacity needs. Thus, non-use of commercial disposal capacity became essentially one of the aspects of "assistance." Or more precisely, it would become DOE "interference" with compact and state development to change this position and attempt to utilize commercial disposal capacity.

\subsubsection{DOE Order 5820.2A, Radioactive Waste Management}

The policies for DOE management of LLW discussed above were incorporated into the revision of DOE Order 5820.2, ${ }^{19}$ and appear in Chapter III, MANAGEMENT OF LOW-LEVEL WASTE, of DOE Order 5820.2A ${ }^{7}$ The most important policy in the Order concerning possible commercial disposal of INEL LLW was developed from the existing policies expressed primarily in the May $1987^{17}$ memorandum and is stated in Section 2. of Chapter III:

\section{Policy.}

c. DOE low-level waste shall be disposed of on the site at which it is generated, if practical, or if onsite disposal capability is not available, at another DOE disposal facility.

\subsubsection{Recent DOE Headquarters Policies}

In 1991, the Envirocare facility obtained a permit from the State of Utah to accept mixed LLW for disposal. This made the facility unique, as the only permitted and licensed mixed LLW 
disposal facility in the country. Increases in budget and management resources came to bear on DOE cleanups. Particularly hard-hit were FUSRAP projects and other long-standing decontamination and decommissioning projects. With the formation of the Office of Environmental Management came an associated need for disposal capacity for large volumes of bulk material such as soil and building materials, and for mixed LLW. This need coincided with the Envirocare facility license and permit to accept and dispose of these types of waste streams, and at a much lower cost than to dispose at one of the DOE facilities.

Thus, the Office of Environmental Restoration began to request exemptions to DOE Order 5820.2A to allow disposal of DOE waste at Envirocare. The first exemption to the Order to allow disposal of DOE-owned LLW was for the Colonie, NY FUSRAP site to dispose of some mixed LLW at Envirocare. This exemption was granted on November 13, 1991.

The Office of Environmental Restoration also requested, and received permission on November 13, 1991, from the Assistant Secretary for Environmental Management to negotiate two large contracts with a commercial disposal facility for disposal of not less than 2 million cubic meters of DOE LLW and just over 53,000 cubic meters of DOE mixed LLW. ${ }^{20}$

While negotiations were in progress with Envirocare to provide DOE with this disposal capacity, the Office of Environmental Restoration received a blanket exemption from the Order by the Assistant Secretary. The blanket exemption was granted on October 12, 1993. ${ }^{21}$ It allowed use of the Envirocare facility without additional permission from DOE Headquarters. The exemption allowed for disposal of small quantities of mixed LLW from any DOE site and for LLW from certain cleanup sites not on DOE-owned land. Several shipments to Envirocare have taken place under the authority of this blanket exemption.

It is critical to understand one of the bases for the Assistant Secretary granting the blanket exemption, and the reason that no compact or state officials objected to the exemption for regular use of the facility by the DOE. The basis is that the waste streams being accepted by Envirocare are not acceptable at the other operating commercial LLW disposal facilities, and have not been included in the planning for new disposal capability. So, there is no perceived interference from DOE waste streams in the division of responsibilities established in the LLRWPAA. Use of the Envirocare facility is consistent with the sensitivities of the DOE regarding possible interference with the states and compacts in developing new disposal capacity.

During the development of the Implementation Plan responding to Defense Nuclear Facilities Safety Board (DNFSB) Recommendation 94-2, the Director of the Midwest Compact Commission, who is also the Convener of the Low-Level Waste Forum, became concerned that part of the Department's response to the Board indicated a potential for a change to the Department's sensitivities towards allowing disposal of DOE LLW in commercial facilities. The Director's letter to the DNFSB ${ }^{22}$ details the position of the states and compacts on the matter of DOE use of commercial facilities. The Director was also concerned about the commitments made by the DOE concerning the potentially changing sensitivities. The response from the DOE to the Director ${ }^{23}$ assures him that DOE has not changed its policy on any of these matters, implying that DOE still has no intention of disposing DOE LLW in commercial disposal facilities intended for states. 


\subsubsection{DOE Order 5820.2B, Waste Management ${ }^{24}$}

The DOE Order on Radioactive Waste Management has been undergoing a revision process for more than two years. The revision is to incorporate requirements for management of waste types other than radioactive waste, thus it will be titled, "Waste Management" when it is issued. A January 23, 1995, draft of the revised Order was ready for review across the DOE Complex. However, mandates based on other Federal Government and Departmental initiatives resulted in the review being postponed.

Based on these initiatives, the January 1995 draft was separated into two documents. The Order contains policies and requirements. A "Guide" contains implementing guidance for the requirements in the Order. The latest draft of this version of the Order revision is dated May 19, 1995. The schedule called for issuance of the new Order on July 31, 1995. At this date, the Deputy Assistant Secretary for Waste Management has asked for an extension of 60 days (and also indicates that additional time may also be necessary) to issue the revised Order. Therefore, the best current estimate is that the revised Order will be issued on or about September 30, 1995.

It is difficult to predict how policies on the DOE use of commercial disposal facilities will appear in Order 5820.2B. However, an examination of the January 1995 draft reveals the prevalent thinking at that time. It is considered by the major DOE and contractor staff working on the revision to be the Department's best effort at the revision. The requirements for management of LLW appeared in Chapter IV of the draft revised Order:

\section{Policy.}

b. DOE low-level waste is to be disposed of at the site where it is generated, if practical. If on-site disposal capability is not available, or cannot be practically developed from a risk and cost-effectiveness basis, the waste may be disposed of at another DOE or non-DOE disposal facility approved in accordance with Chapter I, paragraph 2d, page I-1.

The requirements cited from Chapter I state:

2. Policy.

d. Except as otherwise provided in this Order, non-DOE waste treatment, storage, or disposal facilities may be used by DOE to manage DOE waste, or commercial waste that may be the responsibility of DOE, if:

(1) Such facilities comply with applicable Federal, State, and local statutes and regulations, and have the necessary permits, licenses, and approvals for the specific waste(s) involved;

(2) The DOE Field Element responsible for the waste demonstrates on a case-by-case basis that the use of non-DOE treatment, storage, or disposal facilities is in the best interest of DOE and does not conflict with commercial interests; 
(3) The non-DOE facilities are reviewed by DOE and determined to have adequate operational and regulatory records of performance;

(4) The DOE waste is sufficiently characterized and verified to meet the non-DOE facilities' waste acceptance criteria;

(5) The non-DOE facilities managing DOE waste are reviewed annually by DOE to assess performance and evaluate compliance with applicable requirements and regulations; and

(6) The manager of the applicable Field Element approves the action per paragraph $80(13)$, page 10 of the Order.

e. Potential institutional impacts and long-term liabilities that may result from the use of non-DOE treatment or disposal facilities are to be considered before the transportation of waste to the non-DOE facility.

As can be seen from these provisions of the revised Order, the prevailing attitude of the Department concerning use of commercial disposal facilities is consistent with the recent policy memoranda. DOE is prepared for the regular use of non-DOE commercial disposal facilities as long as the specified conditions are met. Of course, some of these conditions could remain open for debate. For example, the meaning of "in the best interest of DOE and does not conflict with commercial interests," of 2.d (2) is unclear. It could be assumed that this condition is addressing the continued sensitivity of the DOE concerning negatively impacting the progress of states in establishing new disposal facilities under the LLRWPAA. 


\section{FACILITY EVALUATION}

There are currently three licensed commercial disposal facilities which are potentially available for disposal of INEL LLW waste. In order to assess the actual availability of the individual disposal facilities, a comparison was made of INEL LLW with their waste acceptance criteria (WAC) and other requirements. This section documents the results of that comparison. For comparison, the anticipated content and form of the INEL LLW is discussed with the assumptions used to establish the INEL LLW baseline. An overview of each of the disposal facilities is provided. Finally, the results of the comparison are summarized. Also discussed is the methodology used to estimate the quantities of INEL LLW which would be expected to meet the disposal requirements of the respective facilities.

\subsection{INEL LLW Baseline}

The Radioactive Waste Management Complex (RWMC) was established in 1952 as a disposal site for solid, low-level radioactive waste (LLW) and/or mixed low-level waste (MLLW). These wastes were and are generated by operations at the INEL. The completeness and accuracy of the disposal records has varied over the years. Likewise, the volume of waste disposed at the facility has fluctuated significantly as the mission and activities of the INEL have changed. From 1952 through 1992, about $200,000 \mathrm{~m}^{3}$ were disposed at the INEL $\left(-5,000 \mathrm{~m}^{3} / \mathrm{year}\right)$. The annual average disposal rate for the last five years has been about $1,300 \mathrm{~m}^{3} / \mathrm{year}$. Consequently it was decided to use the most recent five-year period as the waste baseline. This time period was selected for the following reasons:

- disposal records were readily available via the computerized Radioactive Waste Management Information System (RWMIS),

- the most recent disposal recurds are considered to be the most accurate and complete, and

- the types of LLW and the content of the most recently disposed waste would be more indicative of future waste than more historical waste types and content.

It should be noted that from 2/91 to 11/94, the Waste Experimental Reduction Facility (WERF) was shut down. About 60 percent of the INEL's LLW is cycled through WERF for compaction, size reduction or incineration before disposal at the RWMC. Based on the achieved reduction ratios, the LLW stockpiled during that time period would reduce the received volumes at RWMC by about 15 percent. However, from a content codes standpoint, the baseline data would be considered representative of both the LLW that goes directly to RWMC and that which cycles through WERF first.

It is recognized that the INEL mission is in a state of flux. The reasons for selecting the waste baseline as described above may not all remain valid. The analysis section briefly discusses the various impacts of potential mission changes.

Selected fields were extracted from the RWMIS database and used for comparison against the requirements of the respective disposal facilities. Table 2 is an example of the type of 
information that was extracted from the database. Figure 1 and Table 3 illustrate the baseline INEL LLW against key parameters (volume, year, waste type, activity, content codes, etc.). It should be noted that the content code field of the database only contains the three most prevalent codes from the hard records. For this study it was deemed that this would provide a fair representation of the contents. Therefore no additional information was obtained from the hard records.

Table 2. Description of fields extracted from the RWMIS.

\begin{tabular}{ll}
\hline \multicolumn{1}{c}{ Field } & \multicolumn{1}{c}{ Description } \\
\hline Site & INEL location of origin \\
NRC class & Calculated NRC class (A, B or C) \\
Container & Unique number associated with each container \\
Container type & Type of disposal container (box, drum, etc.) \\
Volume & Volume of container in cubic meters \\
Weight & Weight of waste and container in grams \\
Activity & Number of curies of activity in the waste \\
Disposal date & Date container disposed of at the RWMC \\
Dose & Contact reading of container \\
Dose units & Units (Rem/hr or mR/hr) of dose \\
CC Code 1 & Code representing primary waste content \\
CC 1\% & Percentage of waste represented by CC Code 1 \\
CC Code 2 & Code representing secondary waste content \\
CC 2\% & Percentage of waste represented by CC Code 2 \\
CC Code 3 & Code representing tertiary waste content \\
CC 3\% & Percentage of waste represented by CC Code 3 \\
Nuclide & Nuclides associated with each container \\
Curies & Curies of each nuclide in each container \\
\hline
\end{tabular}




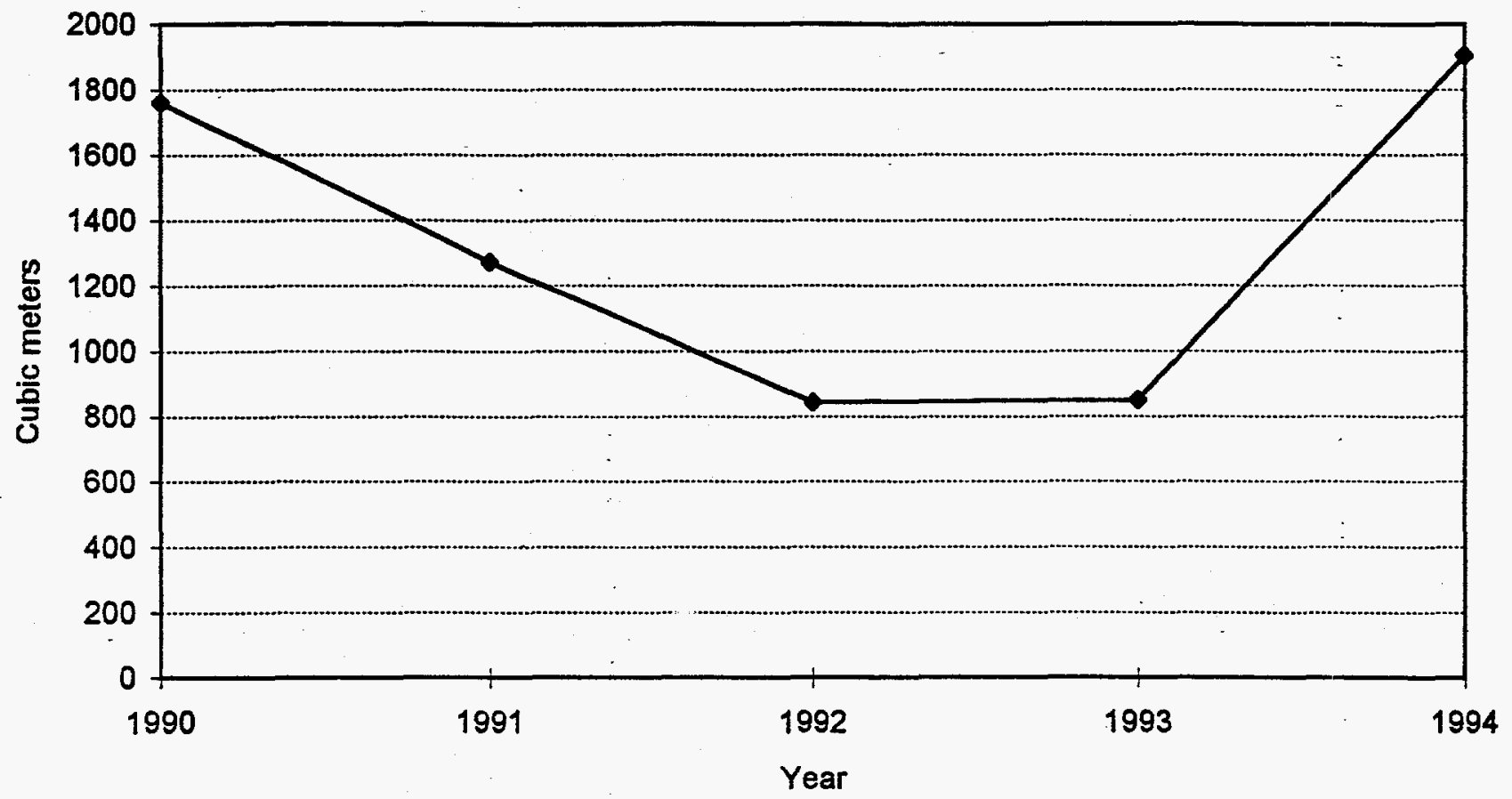

Figure 1. LLW disposed at RWMC (1990-1994). 
Table 3. Selected information extracted form RWMIS (90-94).

\begin{tabular}{|c|c|c|c|c|c|}
\hline Code 1 & Title & $\begin{array}{c}\text { Average } \\
\%\end{array}$ & $\begin{array}{l}\text { Volume } \\
\left(\mathrm{m}^{3}\right)\end{array}$ & $\begin{array}{l}\text { Average } \\
\text { Curies }\end{array}$ & $\begin{array}{l}\text { Average Wt. } \\
(\mathrm{gm})\end{array}$ \\
\hline M41 & METAL COMBINATION - ASSEMBLIES & 77.6 & 1586 & $4.79 \mathrm{E}-01$ & $1.17 \mathrm{E}+06$ \\
\hline S71 & SOIL/GRAVEL/BRICK/CONCRETE RUBBLE & 98.6 & 1007 & $2.20 \mathrm{E}-02$ & $1.69 \mathrm{E}+06$ \\
\hline M83 & NRF-ECF ONLY, M31-20\%, M33-30\%,M41-10,X41-40\% & 99.9 & 649 & $2.00 \mathrm{E}-01$ & $2.38 \mathrm{E}+06$ \\
\hline M31 & METAL - STEEL, CARBON & 87.8 & 603 & $4.00 E-01$ & $2.64 E+06$ \\
\hline $\mathbf{x} 21$ & ANY COMB. OF CLOTH, PAPER, PLASTIC (NONHALO) WOOD & 55.4 & 322 & $3.94 \mathrm{E}-01$ & $8.04 \mathrm{E}+05$ \\
\hline $\mathbf{X} 31$ & ANY COMB. OF FERROUS AND NONFERROUS METAL ARTICLES & 76.0 & 259 & $1.26 \mathrm{E}+02$ & $1.11 \mathrm{E}+06$ \\
\hline 121 & ION EXCHANGE RESIN IN METAL CONTAINMENT & 96.1 & 237 & $1.13 E+01$ & $4.87 \mathrm{E}+06$ \\
\hline $\mathbf{X} 41$ & ANY COMB. GLASS, HALO PLASTIC, LAG.,LIQ.ABS.,MET.C & 60.0 & 198 & $4.72 E+01$ & $1.33 E+06$ \\
\hline S72 & CONCRETE STRUCTURAL COMPONENTS & 99.3 & 176 & $5.23 E-04$ & $6.98 \mathrm{E}+06$ \\
\hline C75 & NRF-ECF ONLY,MLXED STD CC C61-70\%,C51-10\%,X41-20\% & 100.0 & 165 & $3.94 \mathrm{E}+03$ & $3.51 E+06$ \\
\hline S41 & SLUDGE & 100.0 & 144 & $1.01 \mathrm{E}-04$ & $1.08 \mathrm{E}+06$ \\
\hline M21 & METAL - ALUMINUM & 90.9 & 105 & $2.99 \mathrm{E}+00$ & $8.39 E+05$ \\
\hline $\mathbf{W} 21$ & WIRING AND WIRING DEVICES & 100.0 & 94 & $2.27 \mathrm{E}-04$ & $8.93 \mathrm{E}+05$ \\
\hline A61 & RADIOACTIVE CONTAMINATED ASBESTOS & 78.1 & 89 & $1.49 \mathrm{E}-02$ & $9.28 \mathrm{E}+05$ \\
\hline P31 & PAVING (E.G., ASPHALT AND CONCRETE) & 100.0 & 82 & 1.03E-02 & $1.63 \mathrm{E}+06$ \\
\hline M33 & METAL - STEEL, STAINLESS & 75.0 & 65 & $2.31 E+00$ & $2.06 E+06$ \\
\hline A34 & ASH, SOLIDIFIED IN CONCRETE & 100.0 & 61 & $1.55 \mathrm{E}-03$ & $4.91 E+05$ \\
\hline $\mathbf{X} 80$ & NRF-ECF ONLY-MLXED M31-20\%,M33-30\%,M41-10\%,X41-40\% & $\mathbf{8 8 . 0}$ & 59 & $1.34 \mathrm{E}-01$ & $1.72 E+06$ \\
\hline C61 & CORE STRUCTURAL PARTS & 65.2 & so & $1.29 \mathrm{E}+04$ & $2.13 E+06$ \\
\hline X81 & NRF-ECF ONLY-MLXED X71-90\%,M33-10\% RWDS RESIN MOD & 100.0 & 46 & $2.46 \mathrm{E}+01$ & $2.95 E+06$ \\
\hline B22 & BIOLOGICAL WASTE - FECES, VEGETATION & 100.0 & 45 & 3.30E-05 & $1.93 \mathrm{E}+03$ \\
\hline F21 & FILTER - HEPA & 48.6 & 32 & $1.89 \mathrm{E}-02$ & $7.16 \mathrm{E}+05$ \\
\hline M61 & METAL CHIPS OR MISCELLANEOUS SMALL METAL OBJECTS & 56.3 & 27 & $6.42 \mathrm{E}+00$ & $1.38 \mathrm{E}+06$ \\
\hline 122 & ION EXCHANGE RESIN IN CONCRETE CONTAINMENT & 93.3 & 24 & $4.41 E+02$ & $7.42 \mathrm{E}+06$ \\
\hline $\mathbf{R 5 0}$ & HFEF SOUTH FACILITY MODIFICATION WASTE STREAM & 100.0 & 21 & $3.00 \mathrm{E}-01$ & $6.07 \mathrm{E}+05$ \\
\hline M73 & METAL SIZED BY WERF - NONFERROUS & 96.7 & 18 & 3.14E-03 & $5.26 \mathrm{E}+05$ \\
\hline E21 & EVAPORATION DRUM (E.G. SHADE) & 100.0 & 18 & $4.24 \mathrm{E}-02$ & $3.41 \mathrm{E}+06$ \\
\hline A28 & ABSORBED LIQUIDS, NONCOMBUSTIBLE-CLAY & 65.0 & 16 & $4.15 E+01$ & $3.18 E+05$ \\
\hline A28 & ABSORBED LIQUIDS E.G. AQUASET & 65.0 & 16 & 4.15E+01 & $3.18 E+05$ \\
\hline A27 & ABSORBEP LIQUIDS, NONCOMBUST-DIATOMACEOUS EARTH & 50.0 & 15 & $6.38 \mathrm{E}-04$ & $1.60 \mathrm{E}+06$ \\
\hline A31 & ASH, UNSOLIDIFIED & 13.8 & 12 & $5.56 \mathrm{E}-03$ & $5.98 \mathrm{E}+05$ \\
\hline XS1 & ANY COMB. PAVING, ROOFING, SOIL/GRAVEL, BRICK RUBL & 90.6 & 12 & $1.01 E-01$ & $1.41 E+06$ \\
\hline $\mathbf{F} 22$ & FILTER - OTHER THAN HEPA & 10.0 & 11 & $1.08 \mathrm{E}-05$ & $1.31 \mathrm{E}+06$ \\
\hline P41 & PLASTIC - NONHALOGENATED & 100.0 & 11 & $1.40 \mathrm{E}-04$ & $1.47 \mathrm{E}+06$ \\
\hline T10 & TIRES (RUBBER) & 100.0 & 11 & $1.50 \mathrm{E}-04$ & $8.47 \mathrm{E}+05$ \\
\hline P42 & PLASTIC - HALOGENATED & $\mathbf{8 0 . 0}$ & 10 & $7.92 \mathrm{E}+01$ & $9.60 \mathrm{E}+05$ \\
\hline S51 & HFEF NORTH PROCESS \& MAINT WASTE STREAM BLDG 785 & 100.0 & 9 & 4.93E-01 & $6.77 \mathrm{E}+05$ \\
\hline X61 & ANY COMBINATION OF FILTERS & 67.0 & 9 & $1.00 \mathrm{E}-02$ & $1.40 \mathrm{E}+06$ \\
\hline $\mathbf{L 2 0}$ & L\&O LAB BLDG 752 ANALYTICAL LAB WASTE STREAM & 100.0 & 8 & $1.57 \mathrm{E}-02$ & $2.37 \mathrm{E}+05$ \\
\hline F31 & FILTER - LIQUID & $\mathbf{7 2 . 5}$ & 7 & $9.23 \mathrm{E}-02$ & $2.55 E+06$ \\
\hline A20 & ABSORBED LIQUIDS (E.G., HI-LITE) & 80.0 & 6 & $2.24 E+02$ & $1.50 \mathrm{E}+06$ \\
\hline A29 & ABSORBED LIQUIDS, NON-COMB SILICACEMENT OR AMINE & 82.2 & 6 & $5.51 E-03$ & $4.30 E+05$ \\
\hline M23 & METAL - COPPER & 60.0 & 5 & $1.60 \mathrm{E}-04$ & $9.45 \mathrm{E}+06$ \\
\hline A22 & ABSORBED LIQUIDS, NONCOMBUSTIBLE-CEMENT & 91.7 & 4 & $1.92 \mathrm{E}-04$ & $2.90 \mathrm{E}+05$ \\
\hline W31 & WOOD & 35.0 & 4 & $2.50 \mathrm{E}-04$ & $7.74 \mathrm{E}+05$ \\
\hline $\mathrm{C} 62$ & CORE SUBASSEMBLY PARTS & 99.6 & 3 & $1.62 \mathrm{E}+04$ & $3.84 \mathrm{E}+05$ \\
\hline A21 & ABSORBED LIQUIDS, COMBUSTIBLE & 50.0 & 3 & $5.50 \mathrm{E}-05$ & $1.36 \mathrm{E}+06$ \\
\hline M84 & NRF-ECF-WERF ONLY CC M31-30\%,M33-50\%,M41-20\% & 100.0 & 2 & $1.10 \mathrm{E}-04$ & $4.92 \mathrm{E}+05$ \\
\hline 575 & CEMENTED ZR FINES & 100.0 & 2 & $5.70 \mathrm{E}+00$ & $2.27 \mathrm{E}+06$ \\
\hline s31 & SLUDGE EVAPORATOR BOTTOMS - UNSOLIDIFIED & 100.0 & $\mathbf{0}$ & $2.10 \mathrm{E}-04$ & $2.46 \mathrm{E}+05$ \\
\hline X71 & ANY COMBINATION OF RESIN CONTAINERS & 100.0 & 0 & $3.74 \mathrm{E}-03$ & $1.23 \mathrm{E}+05$ \\
\hline A25 & ABSORBED LIQUIDS, NONCOMBUST.FULLERS EARTH OILDRI & 18.0 & $\mathbf{0}$ & $2.62 \mathrm{E}-01$ & $4.09 \mathrm{E}+04$ \\
\hline MS1 & METAL - SPECIAL CASE (E.G., PYROPHORIC IN CONCRETE & 99.0 & $\mathbf{0}$ & 4.92E-11 & $4.06 \mathrm{E}+04$ \\
\hline
\end{tabular}




\subsection{Chem-Nuclear Systems Inc. Facility at Barnwell, South Carolina ${ }^{25}$}

\subsubsection{Historical Background}

The Barnwell LLW disposal facility was originally licensed for above-ground storage of LLW in November 1969. The license was later amended in April 1971 to permit Chem-Nuclear Systems, Inc. (CNSI) as the site operator to bury LLW. CNSI leases the site from the State of South Carolina. As an existing and operating facility at the time the Low-Level Radicactive Waste Policy Act of 1980 was passed, the Barnwell facility was designated as one of three "sited" facilities. Consequently, when South Carolina became the host state for the Southeast Compact in 1986, the Barnwell facility became the designated disposal site for the compact. Its availability to generators from other compacts has been controlled by statute until June of 1995, when South Carolina withdrew from the SE Compact (refer to Section 2, Regulatory Evaluation, of this report for a more detailed description of the statute-controlled availability). The facility is regulated by the South Carolina Department of Health and Environmental Control.

\subsubsection{Site Description}

The site is located on part of the Coastal Plain geologic province. It is characterized by flat, largely unconsolidated sediment layers. Onsite soil consists of a layer of topsoil containing sand, clay, and organic material, overlying a layer of fine sands and silty sands (.5-2 $\mathrm{m}$ thick). This is followed by the sandy clay and dense clays (4-9 $\mathrm{m}$ thick) of the Hawthorne Formation. A regional groundwater table lies within the Hawthorne Formation at depths that range from 9 to $18 \mathrm{~m}$. The principal source of potable water in the area is from the deeper Middendorf Formation at depths in excess of $100 \mathrm{~m}$.

The nearest surface water ( 5 kilometers away) to the site is Lower Three Runs Crcek. This creek, a tributary of the Savannah River, drains the major portion of the site and flows into the river about 110 kilometers downstream. However, because of the gentle slope of the topography and the absorptive nature of the sand cover, surface water runoff occurs only after unusually heavy rainfall.

The climate at the site is mild and humid, with a mean annual precipitation of $120 \mathrm{~cm}$ (ranging from 74 to $185 \mathrm{~cm}$ ). Regionally, about $38 \mathrm{~cm}$ of the annual rainfall infiltrates to the water table. The shallow monitoring wells at the site are screened in the Hawthorne Formation at depths ranging from 11 to $22 \mathrm{~m}$. The water table aquifer flows at a rate of approximately $2 \mathrm{~m}$ per year. Water supply wells in the Barnwell area are screened in the deeper McBean and Middendorf aquifers.

The site currently consists of 73 standard trenches and seven slit trenches. The standard trenches vary dimensionally. The initial four trenches are each about $61 \mathrm{~m}$ long by $15 \mathrm{~m}$ wide by $5 \mathrm{~m}$ deep. The current typical unit is about $300 \mathrm{~m}$ long by $30 \mathrm{~m}$ wide by $6 \mathrm{~m}$ deep. The slit trenches, which are used to dispose of Class $\mathrm{C}$ waste, are approximately $1 \mathrm{~m}$ wide by $150 \mathrm{~m}$ long and about $7 \mathrm{~m}$ deep. 


\subsubsection{Operating Status}

South Carolina became an NRC Agreement State in 1969. As an Agreement State, South Carolina licenses the operation of the LLW disposal facility, through the State Department of Health and Environmental Control, under authority delegated by the NRC. The operating license covers the possession and disposal of source and by-product material. The NRC retains responsibility for licensing the possession and disposal of special nuclear material exceeding certain limits.

LLW is disposed of primarily by shallow-land burial. The disposal trenches are constructed to facilitate the collection and removal of leachate. A floor slopes to one side where a French drain runs the length of the trench and is sloped about $\mathbf{0 . 3}$ percent. Water collection sumps are placed at $150-\mathrm{m}$ intervals along the French drain. Standpipes, for removal of leachate, are located in the sumps and at intervals along the trench. A layer of sand (0.6-1 m thick) is placed on the bottom of each trench to provide an even foundation for waste packages and to ensure that any water entering the trench will drain from the bottom layers of waste and into the French drain for collection. Layers of sand in the trench walls are replaced with compacted clay to reduce lateral infiltration of moisture into the trenches from the surrounding soil.

Waste is typically placed in the trench, starting at the high end of the trench floor, by stacking boxes and components and then filling the intervening spaces with drums and small packages. Upon completion of waste emplacement, trenches are backfilled with sand to fill remaining voids between packages and provide drainage paths away from the waste for any rainwater infiltrate. A layer of soil with a minimum thickness of $1 \mathrm{~m}$ is then placed over the trench, followed by a layer of compacted clay at least .6-m thick. Topsoil, $15-46 \mathrm{~cm}$ deep, is applied and a cover crop planted. The completed trench is located with permanent granite markers at the ends and at the four trench corners, which are keyed to the site records.

Waste with a high surface radiation level is disposed of in slit trenches. The deep, narrow trench aids in minimizing exposure to workers during offloading operations. The trenches are excavated in 38-m segments to prevent cave-ins. Gravel is added to the trench floor in $0.3-1 \mathrm{~m}$ depths to provide rapid water drainage. Once waste is placed in the trench, clay is backfilled over the package to reduce radiation emission from the area. As on the standard trenches, a clay cap and concrete intruder barriers are installed later.

From the beginning of disposal operations in 1971 through 1989 , over $700,000 \mathrm{~m}^{3}$ of waste containing about 7.1 million curies of by-product material were disposed at the site. In addition, almost 15 million $\mathrm{kg}$ of source material and about $3,000 \mathrm{~kg}$ of special nuclear material were disposed in that period.

Effective January 1996, additional engineered barrier requirements will have been imposed upon the facility by the regulators. The increased use of concrete overpacks will be the primary means of achieving compliance.

The Barnwell LLW disposal facility has not had significant problems specifically related to either site operations or to onsite waste management. Waste packaging and transportation violations have been discovered. But, the violations were not severe enough to close the facility. When the volume of waste received at the site increased substantially, and after closure of several 
other LLW disposal facilities, the Governor of South Carolina instituted a program in 1979. The program began a two-year phase-down of the volume of waste accepted at the Barnwell site to $34,000 \mathrm{~m}^{3} /$ year (almost a 50 percent reduction). Later, as a result of the regional compact approach of the Low-Level Radioactive Waste Policy Act and subsequent amendments, additional limitations were placed on volumes and origin of wastes received through 1995. As indicated earlier, South Carolina withdrew from the SE Compact in June 1995. It is once again available to all generators. However, the volume limitations are still applicable since they were incorporated in the license.

\subsubsection{Waste Acceptance Criteria}

CNSI has a 43-page disposal criteria document ${ }^{26}$ containing the full details of the waste acceptance criteria. The purpose of this section is to highlight key aspects for comparison with the other facilities and the candidate waste. Table 4, a matrix of the base NRC criteria vs. WAC for each of the facilities, provides a more detailed presentation.

Solids, gaseous (limited to $\mathrm{Kr}-85$, Xe-133, and tritium meeting certain conditions), and solidified liquid wastes (approved solidification media: vinyl ester styrene, cement, bitumen, vinyl chloride, Aquaset II-H, and Petroset $\mathrm{H}$ ) are accepted for disposal.

All Class B and C waste must be placed in concrete overpacks. Unstabilized Class A waste must be segregated from other wastes in a shipment. Wooden boxes, steel drums and approved highintegrity containers (HICs) are the only acceptable containers for waste. Sorptive media is allowed only for incidental and unintentional liquids in otherwise dry solids. Incidental or trace amounts of oil are acceptable provided they do not exceed one percent (1\%) of waste volume in a container. Radioactively-contaminated asbestos is allowed.

\subsubsection{Disposa! Capacity}

Based upon data through 1993, over $700,000 \mathrm{~m}^{3}$ of waste has been buried at Barnwell. ${ }^{26}$ The available disposal capacity is approximately 1.2 million $\mathrm{m}^{3}$, thus about 44 percent of capacity remains. ${ }^{27}$ However, the new requirement effective January 1996 has been estimated to reduce the effective capacity to about 1 million $\mathrm{m}^{3}$. If the current volume limitation continues, the facility has a remaining life of less than 10 years.

\subsubsection{Disposal Costs}

For the 7/1/95 through 6/30/96 time period, the base disposal fee for standard and special nuclear material ranges from $\$ 59 / \mathrm{ft}^{3}$ to $\$ 77 / \mathrm{ft}^{3}$. An additional $\$ 260 / \mathrm{ft}^{3}$ (state taxes and fees) can be expected for standard waste and containers. Surcharges per shipment based on weight, curie content, shielding and other factors range from $\$ 875$ to $\$ 48,600+$. 
Table 4. NRC criteria vs. facility WACs.

\begin{tabular}{|c|c|c|c|c|}
\hline Criteria & NRC & Barnwell & Richland & Envirocare \\
\hline Physical Form & $\begin{array}{l}\text { Solid, absorbed liquid, gas... } \\
61.56(a)(2) \\
61.56(a)(7)\end{array}$ & $\begin{array}{l}\text { Same except no absorbed } \\
\text { liquids }\end{array}$ & $\begin{array}{l}\text { Same plus liquids (Class A } \\
\text { only not to exceed } 50 \mathrm{ml} \text { in } \\
\text { clinical vials) }\end{array}$ & $\begin{array}{l}\text { Volumetric bulky soil or } \\
\text { soil-like materials or } \\
\text { debris }\end{array}$ \\
\hline $\begin{array}{l}\text { Chemical } \\
\text { Form }\end{array}$ & $\begin{array}{l}\text { No explosive or gaseous } \\
\text { reactions. } \\
61.56(a)(4),(a)(5)\end{array}$ & $\begin{array}{l}\text { Same plus no toluene, } \\
\text { xylene, diacane, scintillation } \\
\text { liquids or other organics }\end{array}$ & Same & \\
\hline Liquid Limits & $\begin{array}{l}\leq 1 \% \text { vol. HIC or } \\
\leq 0.5 \% \text { vol. for other } \\
\text { waste... } \\
61.56(a)(3),(b)(2)\end{array}$ & Same & Same & no free liquids allowed \\
\hline Void Space & $\begin{array}{l}\text { Minimize... } \\
61.56(b)(3)\end{array}$ & $s 15 \%$ vol. for stable waste & $s 15 \%$ vol. for stable waste & $\mathbf{N} / \mathbf{A}$ \\
\hline $\begin{array}{l}\text { Concentration } \\
\text { Averaging }\end{array}$ & $\begin{array}{l}\text { Yes... } \\
61.55(a)(8)\end{array}$ & $\begin{array}{l}\text { Same except for sealed } \\
\text { sources or encapsulated } \\
\text { filters }\end{array}$ & $\begin{array}{l}\text { Same except for } \\
\text { encapsulated filters }\end{array}$ & $\begin{array}{l}\text { Yes, sealed sources } \\
\text { not allowed }\end{array}$ \\
\hline Packaging & $\begin{array}{l}\text { No cardboard or } \\
\text { fiberboard } \\
61.56(a)(1)\end{array}$ & Only wood, steel or HIC & Only metal or HIC & $\begin{array}{l}\text { Bulk waste; containers } \\
\text { emptied at placement }\end{array}$ \\
\hline $\begin{array}{l}\text { Chelating } \\
\text { Agents }\end{array}$ & $\begin{array}{l}>0.1 \% \text { must be identified } \\
\text { and estimated... } \\
20 \text { App. F (I) }\end{array}$ & $\begin{array}{l}\text { s8wt\%; between } 0.1 \% \\
\text { and } 8 \% \text { must be stabilized }\end{array}$ & $\begin{array}{l}\text { Solidify or stabilize } \\
\text { pretreatment conc. of } \\
>1 w t \%\end{array}$ & \\
\hline $\begin{array}{l}\text { Solidification } \\
\text { Media }\end{array}$ & $\begin{array}{l}\text { Test in accordance with } \\
\text { BTP on waste form }\end{array}$ & $\begin{array}{l}\text { Four approved media for } \\
\text { stable waste; two approved } \\
\text { Class } A \text { unstable }\end{array}$ & $\begin{array}{l}15 \text { approved solidification } \\
\text { media; } 4 \text { stabilization media }\end{array}$ & \\
\hline Stability & $\begin{array}{l}\text { HIC, inherent } \\
\text { characteristics or process } \\
\text { Class B \& C } \\
61.56(\text { b)(1) }\end{array}$ & $\begin{array}{l}\text { Same plus Class } A \text { if it has } \\
\text { nuclides with }>5 \text { yr half-life } \\
\text { @ } 21 \mu \mathrm{ci} / \mathrm{cc}\end{array}$ & $\begin{array}{l}\text { Same plus Class A if IX } \\
\text { resin w/ } 21 \mu c i / c c \text { of } \\
\text { nuclides with }>5 \mathrm{yr} \text { half-life }\end{array}$ & \\
\hline Sorptive Media & $\begin{array}{l}\text { Allowable... } \\
61.56(a)(2)\end{array}$ & $\begin{array}{l}\text { Only for incidental and } \\
\text { unintentional liquid }\end{array}$ & $\begin{array}{l}\text { Numerous approved } \\
\text { sorbents }\end{array}$ & \\
\hline Oil & & $\begin{array}{l}\text { s1\% vol. trace and } \\
\text { unintentional }\end{array}$ & $\begin{array}{l}\text { Solidify or stabilize } \\
\text { pretreatment conc. of }>10 \\
\text { w\% }\end{array}$ & . \\
\hline Gas & $\begin{array}{l}\leq 1.5 \text { atm @ } 20^{\circ} \mathrm{C} \text { and } \max . \\
100 \text { curies... } \\
61.56(\mathrm{a})(7)\end{array}$ & $\begin{array}{l}\text { Only } K_{r}-85 \text { and } X e-133 \text { at } \\
\text { same conditions; sealed } \\
\text { tritium sources } \leq 1000 \\
\text { curies }\end{array}$ & Same & \\
\hline $\begin{array}{l}\text { Biological } \\
\text { Waste }\end{array}$ & $\begin{array}{l}\text { Must be treated to reduce } \\
\text { biological, pathogenic, or } \\
\text { infectious hazards... } \\
61.56(\mathrm{a})(8)\end{array}$ & $\begin{array}{l}\text { Doubly packaged meeting } \\
\text { five specific criteria }\end{array}$ & $\begin{array}{l}\text { Doubly packaged meeting } \\
\text { four specific criteria }\end{array}$ & \\
\hline
\end{tabular}


Table 4. (continued).

\begin{tabular}{|c|c|c|c|c|}
\hline Criteria & NRC & Barnwell & Richland & Envirocare \\
\hline Pyrophorics & $\begin{array}{l}\text { Treat or package to be } \\
\text { non-flammable... } \\
61.56(a)(6)\end{array}$ & Same & Same & \\
\hline $\begin{array}{l}\text { Source } \\
\text { Material }\end{array}$ & & 60,000 pounds & $\begin{array}{l}36,000 \mathrm{~kg} \text {; will accept large } \\
\text { volumes of NORM }\end{array}$ & \\
\hline SNM & & $\begin{array}{l}200 \mathrm{gm} \mathrm{U}-233 \text { or } 350 \mathrm{gm} \\
\text { U-235 max, per package }\end{array}$ & $\begin{array}{l}60 \mathrm{gm} \text { of } \mathrm{U}-233 \text { or } \mathrm{Pu}, 100 \\
\mathrm{gm} \text {. of } \mathrm{U}-235 \mathrm{max} \text {. per } \\
\text { package }\end{array}$ & $\begin{array}{l}200 \mathrm{gm} \mathrm{U}-233 \text { or } \mathrm{Pu}, \\
350 \mathrm{gm} \mathrm{U-235}\end{array}$ \\
\hline $\begin{array}{l}\text { Incinerator } \\
\text { Ash }\end{array}$ & & $\begin{array}{l}\text { Treat or package to be } \\
\text { non-dispersible }\end{array}$ & Treat to be non-dispersible & \\
\hline $\begin{array}{l}\text { Dewatered } \\
\text { Resin }\end{array}$ & $\begin{array}{l}\text { Yes... } \\
61.56(a)(3),(b)(2) \\
\text { BTP C.3 \& C. } 4\end{array}$ & Yes & Yes & \\
\hline Transuranics & & $\begin{array}{l}\text { Activity must be evenly } \\
\text { distributed and incidental. } \\
\text { Accepts whole smoke } \\
\text { detectors }\end{array}$ & $\begin{array}{l}\text { Activity must be evenly } \\
\text { distributed and incidental. } \\
\text { Accepts whole smoke } \\
\text { detectors }\end{array}$ & \\
\hline Other & - & $\begin{array}{l}\text { Shielding lead } \\
\text { No PCBs } \\
\text { Asbestos }\end{array}$ & $\begin{array}{l}\text { Silent re: lead, PCB, } \\
\text { asbestos }\end{array}$ & $\begin{array}{l}\text { Separate mixed waste } \\
\text { disposal cell, asbestos }\end{array}$ \\
\hline
\end{tabular}

\subsection{Envirocare of Utah Inc., Facility at Clive, Utah ${ }^{28}$}

\subsubsection{Historical Background}

The history of the Envirocare facility dates back nearly 20 years. In 1976, the DOE began the site evaluation process for a uranium mill tailings disposal project. After nearly eight years of study among 29 potential sites, DOE determined that the Clive, Utah location exhibited the most suitable hydrogeological, ecological, and economical characteristics. A favorable Environmental Impact Statement for the Clive site was issued in July 1984. After completion of the DOE project, Envirocare acquired the surrounding property for the development of a radioactive waste disposal facility.

The initial disposal facility was licensed by the Utah Department of Health, Bureau of Radiation Control for the disposal of naturally-occurring radioactive material (NORM) wastes in February 1988. The license was modified in March 1991 to allow the disposal of other largevolume wastes with low concentrations of other than NORM radioactive constituents. Such wastes include contaminated soil and contaminated debris. The large volumes and low specific activity of these wastes have traditionally precluded their acceptance for disposal at other licensed LLW disposal facilities. Adjacent to the NORM/LLW disposal facility is a RCRA-permitted facility for the disposal of mixed waste that began operation in April 1992.

Envirocare is currently licensed by the Nuclear Regulatory Commission and the Utah Division of Radiation Control and Solid and Hazardous Waste to provide permanent disposal 
services for four classes of mildly radioactive materials. They are NORM, LLW, 11e.(2), and mixed radioactive/RCRA hazardous wastes.

\subsubsection{Site Description}

Envirocare is located in Tooele County, Utah. It is approximately 140 kilometers west of Salt Lake City along Interstate 80. The facility is directly south and adjacent to the cell used for disposing mill tailings removed from the former Vitro Chemical company site in South Salt Lake City between 1984 and 1988.

The climate at the Envirocare facility is arid desert (evapotranspiration is at least 5 times precipitation) with an average annual rainfall of about $13 \mathrm{~cm}$ per year. The water in the groundwater system is $9 \mathrm{~m}$ beneath the site. It is briny and contains high total dissolved solids and certain naturally-occurring radionuclides that make it unfit for human consumption. There are no perennial surface water bodies within 3 kilometers of the site, nor even gullies that would indicate intermittent channelized flow.

Most of the land within a 16-kilometer radius of the site is public domain administered by the Bureau of Land Management. There are no industrial, commercial, or residential activities within at least 16 kilometers of the site. The lack of potable water makes the surrounding area an improbable location for any future developments.

Surface soils at Envirocare consist of light brown to tan sandy to clayish silt. The thickness of these surface soils ranges from about $1 \mathrm{~m}$ to $4 \mathrm{~m}$. Underlying the surface soils is an interlayered sequence of material ranging from fine- and medium-grained sands to silty clays. This interlayered sequence extends to depths of about $15 \mathrm{~m}$ below existing grade. Beneath the interlayered sequence, the predominant material is a grayish-brown to brown silty sand with a consistency classification of medium dense to very dense.

\subsubsection{Operating Status}

Using a continuous "cut and cover" process, radioactive waste materials are deposited in $30.5-\mathrm{cm}$ layers and then compacted. The disposal cell or embankment is partly above grade and partly below grade. A typical cell extends approximately $3 \mathrm{~m}$ below grade. The bottom $0.3 \mathrm{~m}$ of the cell consists of a scarified and re-compacted clay liner to retard seepage from the cell into the undisturbed soil. The maximum height of the cell above-grade, exclusive of the cover, is about $8.5 \mathrm{~m}$.

The disposal cell cover is designed in accordance with NRC guidance on covers for uranium mill tailings piles. A 2.3-m thick compacted clay layer serves as a radon barrier. This clay layer is topped with a $15-\mathrm{cm}$ thick layer of sand and a 0.5 -m thick layer of rip-rap. The rip-rap layer is designed to resist water and wind erosion as well as discourage burrowing animals and plant root intrusion.

When Envirocare's mixed waste disposal facility opened for operation, Envirocare was inundated with auditors. They evaluated past performance in support of placing mixed waste disposal contracts. The NORM and LLW disposal practices were the basis of the audits. The 
results of the audits and reviews, conducted by commercial and government entities, indicated minor license infractions and fines, but no significant violations.

\subsubsection{Waste Acceptance Criteria}

Envirocare administers its waste acceptance criteria using a five-step qualification process. The process is initiated via an initial "qualification sheet" accompanied by a letter from the applicable compact allowing export of the waste. Samples are then submitted to a Utah certified lab and the results are used to complete the profile (radiological and physical properties) forms. The completed profile forms are then submitted to Envirocare with representative samples for Envirocare to establish "fingerprint" acceptance ranges for ultimate acceptance of individual shipments.

Acceptable material is limited to volumetric bulky soil or soil-like materials or debris. Acceptable packaging ranges from bulk rail car or truck shipments to containerized waste. Containerized waste is removed from the container prior to placement in the disposal cell. Acceptable levels of radioactivity are characterized as very low in comparison to the other commercial disposal facilities. Depending on the nuclide, Envirocare's maximum average concentration in the waste for disposal ranges from 1-4 orders of magnitude below the other commercial disposal facilities.

\subsubsection{Disposal Capacity}

Based on the pathways analysis that was performed to support the licensing process, the LLW disposal facility has a capacity of over 2.8 million $\mathrm{m}^{3}$. The latest annual report submitted to the regulators indicates that less than 10 percent of the capacity has been filled. Company officials also indicate that additional cells can be added to the facility if more disposal capacity is needed.

\subsubsection{Disposal Costs}

The Army Corps of Engineers has negotiated a large-volume disposal contract for use by Federal agencies. The cost per cubic foot varies according to packaging and quantity. The range is from $\$ 7.29 / \mathrm{ft}^{3}$ to $\$ 8.65 / \mathrm{ft}^{3}$ for soils to $\$ 17 / \mathrm{ft}^{3}$ for waste containing more than 10 percent debris.

\subsection{U.S. Ecology Facility at Richland, Washington ${ }^{b}$}

\subsubsection{Historical Background}

The disposal site was licensed and opened as a commercial venture in September 1965 and, except for a brief period in 1979, has operated since that time. The first licensed operator of the site was California Nuclear, Inc. In March 1968, the assets of the company were transferred to the Nuclear Engineering Company, which in 1981 changed its name to U.S. Ecology, Inc.

Washington has been an Agreement State with the NRC since December 1966. Since that time, the State has assumed responsibility for licensing the possession and disposal of source and

b. Significant portions of this section have been condensed from related material in reference 24 . 
by-product material. The NRC retains responsibility for licensing the possession and disposal of special nuclear material exceeding certain limits.

Disposal practices other than the conventional method of disposal in shallow trenches have been used at the Richland facility. These include using caissons and resin tanks. Five underground steel tanks, ranging in size from 1,000 to 20,000 gallons, were installed in the late 1960 s for evaporating and solidifying liquid resin wastes. Their use was discontinued in the early 1970s. The tanks and associated wastes were left in place with little attention until early 1985. At that time, leaks in the tanks and contamination of adjacent soils were discovered. U.S. Ecology Inc., removed the liquid waste from the tanks and subsequently removed and disposed of two of the five tanks. The remaining three tanks were filled with concrete. Plastic was placed over the tank area to prevent the contaminated soil from becoming airborne.

\subsubsection{Site Description}

The Richland commercial LLW disposal site is located on the central plateau of the Hanford Reservation. It is about 37 kilometers northwest of Richland, Washington, in the southeastern part of the State. The site consists of 100 acres leased by U.S. Ecology, Inc., from a 1,000-acre tract on the Hanford Nuclear Reservation that is leased by the State of Washington from DOE.

The Hanford Reservation is located in the Pasco Basin on the semiarid alluvial plain of the Columbia River. The disposal site is situated on glacier-fed river sediments of the ancestral Columbia River that consist of sand, silt, and gravel in various combinations. These deposits are up to about $60 \mathrm{~m}$ deep and overlay the Reingold Formation, which is a layer of sedimentary material up to $365 \mathrm{~m}$ thick. Below this formation, the bedrock consists of Yakima Basalt. The land is generally flat with intermittent dunes, except where grading has occurred. The depth of the water table beneath the disposal site is about $75 \mathrm{~m}$. The bottom of this unconfined aquifer is coincidental with the lowest layers of the Reingold Formation.

The Columbia River flows through the reservation about 10 kilometers from the commercial LLW disposal site. There are no surface-water bodies on or near the disposal site. Two intermittent streams and a small natural pond are located on the surrounding reservation.

The Pasco basin is characterized by a semiarid climate, with an average annual precipitation of about $16 \mathrm{~cm}$ and an annual potential evaporation rate of $140 \mathrm{~cm}$.

The commercial LLW disposal site is essentially bounded on the east and west sides by two DOE radioactive waste disposal areas. They have been used for the disposal of waste since 1944 and are still in active use. The proximity of the commercial LLW disposal site to the DOE disposal areas complicates the ability to distinguish by environmental monitoring potential releases from the LLW site from potential releases from the DOE sites.

The site consists of 18 land disposal trenches that vary dimensionally from 90 to $300 \mathrm{~m}$ long, 7.6 to $46 \mathrm{~m}$ wide, and 6 to $14 \mathrm{~m}$ deep. The site also hosts four 9-m-deep caissons used for the disposal of waste with high surface radiation readings. The caissons consist of four wells, $9 \mathrm{~m}$ deep and lined with steel pipe, which are closed off at both ends with concrete. 


\subsubsection{Operating Status}

Washington was a member of the Northwest Compact Region when it was approved by Congress in 1985. As one of the three sited States, Washington was obligated to allow the Richland facility to dispose of wastes generated outside the compact. This obligation was through 1992 , as long as the States in which the generators were located continued to meet the milestone prescribed in the LLRWPAA of 1985.

LLW is disposed of primarily by shallow land burial. The disposal trenches are opened, as needed, and used in an alternating sequence to allow room for the stockpiling of excavated soil and to facilitate trench access. The waste containers are placed in the trench, with a minimum distance of $2.44 \mathrm{~m}$ between the top of the waste and the original ground surface. The trench is backfilled with the previously excavated soil. After the trench is filled to the original level, a soil cover is formed into a mound which is at least $1.5 \mathrm{~m}$ thick along the trench centerline and $1 \mathrm{~m}$ thick near the trench edge. A 15-cm layer of cobble and gravel is then placed on the mound to protect the cover soil against wind erosion and burrowing animal intrusion.

During the period between the beginning of waste disposal operations in 1965 and the end of 1993 , over $350,000 \mathrm{~m}^{3}$ of waste, which contained about 34 million curies of by-product material, were disposed at the Richland site. In addition, over 6 million $\mathrm{kg}$ of source material and about $160 \mathrm{~kg}$ of special nuclear material were disposed in the same period.

Except for the underground tanks, the Richland LLW disposal facility has experienced no problems related to site operations or waste containment. However, as with the Barnwell facility, routine inspections of incoming waste in 1979 led to the discovery of violations of transportation and packaging regulations. Consequently, the disposal site was shut down by the Governor of Washington during October and November of 1979 until the problems were corrected.

\subsubsection{Waste Acceptance Criteria}

U.S. Ecology enforces a 36-page radioactive materials license establishing the WAC. The purpose of this section is to highlight key aspects for comparison with the other facilities and the candidate waste. Solids, gaseous (no nuclide limitation, just pressure and curie limits), and solidified liquid wastes (15 approved solidification media) are accepted for disposal. Metal drums or boxes having a heavy-duty closure device and approved high-integrity containers (HICs) are the only acceptable containers for waste. Sorptive media may be used for liquids and include many clays, diatomaceous earths, perlites, and others. Waste liquids which have a pretreatment oil concentration in excess of 10 percent by weight are acceptable provided they are treated by either solidification or stabilization.

\subsubsection{Disposal Capacity}

The volume disposed to date at the Richland facility is just under $400,000 \mathrm{~m}^{3}$ of waste. The available disposal capacity is approximately 1.6 million $\mathrm{m}^{3}$, thus just over 75 percent of capacity remains. ${ }^{29}$ 


\subsubsection{Disposal Costs}

The base disposal rate effective July 1, 1995, is $\$ 37.61$ per cubic foot. Exposure surcharges range up to $\$ 32.15$ per cubic foot. Surcharges for liners/barriers range up to $\$ 5,118.12$. A perload surcharge for curies ranges from $\$ 0$ (less than 50 curies) to $\$ 9,300.90+$ (greater than 15,000 curies. Percentage rate reductions for decommissioning waste ( 25 percent reduction) and extraordinary volumes ( 48.5 percent reduction) can be applied. Additional taxes and fees amount to $\$ 10.80$ per cubic foot and 4.45 percent of rates and charges.

\subsection{Waste/Facility Matrix}

Table 5 is an example of the waste/facility matrix that formed the keystone of the database manipulations. These manipulations were used to estimate the amount of INEL LLW that could conceivably qualify for disposal at the respective commercial facilities. Additional data not shown on the example matrix was used to verify or modify the yes/no criteria for each facility. Examples are the range of activity associated with particular content codes, specific nuclide activity (particularly important for Envirocare determinations), and calculated NRC class. A similar matrix was prepared for each of the content codes.

Various queries of the database were then run using the information in the matrix to total the volumes that could be expected to meet the respective WACs. For some of the waste descriptions the yes/no determination was debatable. For those cases additional queries were run to determine the impact. The results generally ranged from 70-80 percent acceptability for the Barnwell and Richland facilities and 17-25 percent for the Envirocare facility. 
Table 5. Example Waste/Facility Matrix.

\begin{tabular}{|c|c|c|c|c|}
\hline $\begin{array}{c}C C \\
\text { Code } 1\end{array}$ & Title & Barnwell & Hanford & Envirocare \\
\hline A20 & Absorbed liquids (e.g., hi-lite) & No & No & No \\
\hline A21 & Absorbed liquids, combustible & No & No & No \\
\hline A22 & Absorbed liquids, noncombustible-cement & No & No & No \\
\hline A25 & Absorbed liquids, noncombust.-fullers earth oildri & No & Yes & No \\
\hline A27 & Absorbed liquids, noncombust-diatomaceous earth & No & Yes & No \\
\hline A28 & Absorbed liguids, noncombustible-clay & No & Yes & No \\
\hline A28 & Absorbed liquids e.g., aquaset & No & Yes & No \\
\hline A29 & Absorbed liquids, non-comb silica/cement or amine & No & Yes & No \\
\hline A31 & Ash, unsolidified & No & No & No \\
\hline A34 & Ash, solidified in concrete & Yes & Yes & Yes \\
\hline A61 & Radioactive contaminated asbestos & Yes & No & Yes \\
\hline B22 & Biological waste - feces, vegetation & Yes & Yes & Yes \\
\hline C61 & Core structural parts & Yes & Yes & No \\
\hline C62 & Core subassembly parts & Yes & Yes & No \\
\hline $\mathbf{C 7 5}$ & NRF-ECF only,mixed std CC C61-70\%, C51-10\%, X41-20\% & No & Yes & No \\
\hline E21 & Evaporation drum (e.g., shade) & No & No & No \\
\hline F21 & Filter - HEPA & Yes & Yes & No \\
\hline $\mathbf{F} 22$ & Filter - other than HEPA & Yes & Yes & No \\
\hline F31 & Filter - liquid & Yes & Yes & No \\
\hline $\mathrm{I} 21$ & Ion exchange resin in metal containment & No & No & No \\
\hline 122 & Ion exchange resin in concrete containment & No & No & No \\
\hline L20 & L\&O lab bidg 752 analytical lab waste stream & No & No & No \\
\hline M21 & Metal - aluminum & Yes & Yes & No \\
\hline M23 & Metal - copper & Yes & Yes & No \\
\hline M31 & Metal - steel, carbon & Yes & Yes & No \\
\hline M33 & Metal - steel, stainless & Yes & Yes & No \\
\hline M41 & Metal combination - assemblies & Yes & Yes & No \\
\hline M51 & Metal - special case (e.g., pyrophoric in concrete) & Yes & Yes & No \\
\hline M61 & Metal chips or miscellaneous small metal objects & Yes & Yes & No \\
\hline M73 & Metal sized by WERF - nonferrous & Yes & Yes & No \\
\hline M83 & NRF-ECF only, M31-20\%, M33-30\%, M41-10, X41-40\% & Yes & Yes & No \\
\hline M84 & NRF-ECF-WERF only CC M31-30\%, M33-50\%, M41-20\% & Yes & Yes & No \\
\hline P31 & Paving (e.g., asphalt and concrete) & Yes & Yes & Yes \\
\hline P41 & Plastic - nonhalogenated & Yes & Yes & No \\
\hline P42 & Plastic - halogenated & Yes & Yes & No \\
\hline R50 & HFEF south facility modification waste stream & No & No & No \\
\hline S31 & Sludge evaporator bottoms - unsolidified & No & No & No \\
\hline S41 & Sludge & No & No & Yes \\
\hline S51 & HFEF north process \& maint waste stream bldg 785 & No & No & No \\
\hline S71 & Soil/gravel/brick/concrete rubble & Yes & Yes & Yes \\
\hline S72 & Concrete structural components & Yes & Yes & Yes \\
\hline S75 & Cemented $\mathrm{Zr}$ fines & Yes & Yes & No \\
\hline T10 & Tires (rubber) & Yes & Yes & No \\
\hline W21 & Wiring and wiring devices & Yes & Yes & No \\
\hline W31 & Wood & Yes & Yes & No \\
\hline $\mathrm{X} 21$ & Any comb. of cloth, paper, plastic (nonhalo) wood & Yes & Yes & No \\
\hline $\mathrm{X} 31$ & Any comb. of ferrous and nonferrous metal articles & Yes & Yes & No \\
\hline $\mathrm{X} 41$ & Any comb. glass, halo plastic, lag., liq. Abs., met. C & No & Yes & No \\
\hline X51 & Any comb. paving, roofing, soil/gravel, brick rubl & Yes & Yes & No \\
\hline X61 & Any combination of filters & Yes & Yes & No \\
\hline X71 & Any combination of resin containers & No & No & No \\
\hline X80 & $\begin{array}{l}\text { NRF-ECF only-mixed M31-20\%, M33-30\%, M41-10\%, X41- } \\
40 \%\end{array}$ & No & No & No \\
\hline X81 & NRF-ECF only-mixed X71-90\%, M33-10\% rwds resin mod & No & No & No \\
\hline
\end{tabular}




\section{OTHER ISSUES}

One of the constraints of the study was that regulators not be contacted. In the State of Washington, the chairman of the Northwest Compact is a state regulator. Since disposal of Federal waste at the commercial facility in Richland is governed by the NW Compact, the potential availability of the facility for INEL LLW cannot be fully assessed at this time. There is enough uncertainty and repositioning regarding LLW disposal nationally that the specific political climate in Washington cannot be determined without contacting the regulators. There is no technical basis for regulators and compact officials to differentiate between commercial and DOE waste from the standpoint of safety and protection of human health and the environment. However, history has shown that the social and political climate greatly influence the final decisions regarding disposal of LLW.

A similar situation exists relative to the Barnwell facility. The recent movement of South Carolina out of the SE Compact and the subsequent increased availability of the facility to generators would infer a more receptive atmosphere. However, the real posture of the regulators, state officials, and the local community needs to be assessed. 


\section{ANALYSIS AND CONCLUSIONS}

Based on the evaluations of the statutory and regulatory frameworks, and the DOE policies associated with commercial disposal of DOE LLW, it would appear to be an opportune time to pursue some commercial disposal of INEL LLW.

There are no statutory restrictions on the commercial disposal of DOE LLW. The responsibilities sections of the LLRWPAA clarify congressional preferences for management of LLW generated by commercial interests and the Federal Government. But, the law does not prohibit the disposal of commercial LLW in DOE sites, or DOE LLW in commercial sites. In fact, it could be argued that the framers of the law expected some of the crossover to occur. This is evidenced by provisions of the law that specify the conditions that must exist for Federal Government LLW to be disposed in a compact or state LLW disposal facility.

Furthermore, there are no restrictions placed on acceptance of DOE LLW by the Northwest Compact by-laws for either the Richland or Envirocare facilities. The by-laws are clear that the Compact can make any arrangements it desires with other states, compacts, or individual generators. The restrictions placed on acceptance of DOE LLW at Envirocare are primarily associated with policies of the DOE. Those restrictions are reflected in the contracts negotiated between DOE and Envirocare. The Northwest Compact's Resolution and Order allowing Envirocare's operations also contains restrictions on waste origin. However, the Resolution and Order was recently amended to allow disposal of LLW streams from operations and routine cleanups, providing the radionuclide limitations of the license are still met. This implies that if the DOE requested access to Envirocare for some of these types of LLW, the Northwest Compact may find it acceptable to include cleanup LLW.

Since South Carolina seceded from the Southeast Compact, there is no longer any legal authority for South Carolina to restrict access to the Barnwell facility. Even if all the INEL LLW were to go to Barnwell, it would only amount to about 4 percent of the annual limitation of waste receipts. The capacity impacts at the other facilities is much less.

The regulatory framework for commercial LLW disposal contains no special restrictions or provisions that would affect disposal of INEL LLW. As was the case at Envirocare, meeting the disposal facility waste acceptance criteria and any other provisions of the license issued by the appropriate regulatory authority would allow acceptance of DOE LLW at Barnwell, Richland, and Envirocare.

The two major areas of uncertainty regarding the feasibility of commercial disposal of INEL LLW are the social/political climate and the policy of the DOE that it will not interfere with the compact and regional disposal process being implemented under the LLRWPAA. The DOE has assured states and compacts that DOE LLW will not be disposed at commercial LLW facilities. The use of the Envirocare facility has been viewed as acceptable because the wastes being received there were not going to be received by LLRWPAA LLW facilities.

At this juncture, the actions of the South Carolina Legislature and the Northwest Compact in removing restrictions to receipt of LLW at the Barnwell, SC and Envirocare, UT disposal facilities could be inferred as a statement that the LLRWPAA process is not working as originally conceived. Thus, any actions by the DOE that would have been viewed as "interference" may not necessarily be viewed that way anymore. Regardless of any inference that can be drawn, the DOE, if it decided at this time to begin utilizing any or all of the commercial disposal facilities, would need to communicate 
with any, and perhaps all, parties to which it has stated it would not use commercial disposal facilities.

There is a significant portion of very low activity soil which has been in storage for several years at the INEL because it is considered too low in activity for acceptance by RWMC but too high for unmonitored discard. The Idaho Chemical Processing Plant has been storing over 1200 boxes of such soil for several years. As environmental remediation work continues at the INEL, more stockpiles of such soil would be expected. This was exactly the scenario for which Envirocare established its LLW disposal facility. Due to the ready availability, favorable disposal costs, existing contract for Federal waste, and ample capacity, the use of Envirocare is considered the most feasible of the commercial disposal options. 


\section{REFERENCES}

1. Atomic Energy Act of 1954, Public Law 83-703.

2. Low-Level Radioactive Waste Policy Act of 1980, Public Law 96-573.

3. Low-Level Radioactive Waste Policy Amendments Act of 1985, Public Law 99-240.

4. Regulating the Disposal of Low-Level Radioactive Waste, A Guide to the Nuclear Regulatory Commission's 10 CFR Part 61, NUREG/BR-0121, U.S. Nuclear Regulatory Commission, Office of Nuclear Material Safety and Safeguards, August 1989.

5. Framework for DOE Low-Level and Mixed Low-Level Waste Disposal: Current Overview, DOE/ID-10484, U.S. Department of Energy, Office of Waste Management (EM-30), June 1994.

6. Bylaws of the Committee for the Northwest Interstate Compact on Low-Level Waste Management, Northwest Interstate Compact, October 1983.

7. DOE Order 5820.2A, "Radioactive Waste Management." September 6, 1988.

8. Analysis of the Legal, Regulatory, and Technical Issues Associated with DOE Accepting Commercial Mixed Waste, DOE/LLW-180, National Low-Level Waste Management Program, June 1993.

9. 1993 Annual Report on Low-Level Radioactive Waste Management Progress, Report to Congress, DOE/EM-0236, U.S. Department of Energy, Office of Environmental Management, November 1994.

10. Amended Resolution and Order, Northwest Interstate Conpact on Low-Level Radioactive Waste Management, April 1995.

11. LLW Notes, LLW Forum, Volume 10, Number 4, June 1995.

12. Personal Communication with Holmes Brown, Afton \& Associates, August 2, 1995.

13. EPA Standards Delayed by Low Priority and Coordination Problems, GAO/RCED-93-126, United States General Accounting Office, June 1993.

14. Scope of EPA Low-Level Waste Rule Narrowed, Environment Reporter, The Bureau of National Affairs, Inc., July 21, 1995.

15. Telecommunications Message, C.E. Williams to Distribution, U.S. Department of Energy, October 26, 1979.

16. Memorandum, S. Meyers to Distribution, U.S. Department of Energy, November 19, 1979.

17. Memorandum, S. R. Foley to Distribution, U.S. Department of Energy, May 11, 1987.

18. Memorandum, B. Twining to Distribution, U.S. Department of Energy, March 3, 1988. 
19. DOE Order 5820.2, "Radioactive Waste Management." 1984.

20. Memorandum, EM-421 to L. Duffy, U.S. Dept. of Energy, September 13, 1991.

21. Memorandum, T. Grumbly to various, U.S. Dept. Of Energy, October 12, 1993.

22. Letter, G. Larson to Defense Nuclear Facilities Safety Board, Midwest Interstate Low-Level Radioactive Waste Commission, December 14, 1994.

23. Memorandum, Jill E. Lytle to G.S. Larson, U.S. DOE, January 30, 1995.

24. Waste Management, Unpublished Internal Draft Order 5820.2B, U.S. Department of Energy, January 1995.

25. Selected information condensed from Directions in Low-Level Radioactive Waste Management: A Brief History of Commercial Low-Level Radioactive Waste Disposah DOE/LLW-103, Rev.1, August 1994.

26. Joseph J. Still, Barnwell Waste Management Facility Site Disposal Criteria, Chem-Nuclear Systems, Inc., S20-AS-010, 2/16/95.

27. Low-Level Radioactive Waste Policy Act Report: Response to Public Law 96-573, U.S. Department of Energy, DOE/NE-0015, 1980.

28. Selected information extracted from promotional literature and R.D. Baird, et.al., Evaluation of the Potential Public Health Impacts Associated with Radioactive Waste Disposal at a Site Near Clive, Utah, Rogers and Associates Engineering Corporation, REA-9004/2-1, June 1990.

29. Low-Level Radioactive Waste Policy Act Report: Response to Public Law 96-573, U.S. Department of Energy, DOE/NE-0015, 1980. 